\title{
Tectonic Analysis of the Al Hamadah Al Hamra Plateau of the Ghadamis Basin (NW Libya): Hydrological Network, Sinkholes, Folds and Fractures. Style of Reactivation and Setting of Cenozoic Volcanism
}

\author{
Mahmoud A. Benissa1, Jean Chorowicz ${ }^{2}$ \\ ${ }^{1}$ Exploration Department, Libyan Petroleum Institute, Tripoli, Libya \\ ${ }^{2}$ Institut des Sciences de la Terre de Paris (iSTeP), Sarbonne Universités, Paris, France \\ Email: m.benissa@lpilibya.com, Benissa_lpi@yahoo.com, jean.chorowicz@free.fr
}

How to cite this paper: Benissa, M.A. and Chorowicz, J. (2019) Tectonic Analysis of the Al Hamadah Al Hamra Plateau of the Ghadamis Basin (NW Libya): Hydrological Network, Sinkholes, Folds and Fractures. Style of Reactivation and Setting of Cenozoic Volcanism. International Journal of Geosciences, 10, 527-562.

https://doi.org/10.4236/ijg.2019.105031

Received: October 14, 2018

Accepted: May 10, 2019

Published: May 13, 2019

Copyright $\odot 2019$ by author(s) and Scientific Research Publishing Inc. This work is licensed under the Creative Commons Attribution International License (CC BY 4.0).

http://creativecommons.org/licenses/by/4.0/

\begin{abstract}
Remote sensing analysis is an efficient tool for updating geological maps. The regional scale map obtained in this project from compilation of the pre-existing maps and of a number of space images is somewhat more complete. It takes into account the usual field and laboratory parameters of the rock units, through the previous geologic maps, together with remote sensing parameters such as spectral signatures, textures, roughness, morphology that are observed from optical, microwave and DEM imagery. With more rock characteristics, the old maps are obligatory improved. The Cenozoic faulting in the Al Hamra al Hamadah plateau is largely influenced by the tectonics affecting the Paleozoic oil bearing structures that are hidden by the late Cretaceous-Paleocene layers. The tectonic style is that of reactivation of the Paleozoic faults under effects of the NNE-trending regional tension. Then the faults on the surface of the plateau would indicate location of the hidden Paleozoic faults in depth. A flat plateau, in the arid environment, appears to be a very favorable environment for mapping of gentle folds, faults and tectonic sinkholes. Remote sensing is a fruitful approach in this case study. The gentle anticlines for instance are undetectable in the field, but computer assisted shadowing with a low elevation angle of illumination is the key processing for evidencing these features. Problems of drillings in the area are well known for example to Waha, AGOCO and PB Companies during their exploration activities in the concessions in Ghadames Basin. According to them several incidents of losing drilling Pits have occurred and drilling came into a hole. Because this paper is aimed to know the exact location of sinkholes in the
\end{abstract}


Ghadames basin, I would recommend all the oil companies to review this work and try to trace the sinkholes indicated to minimize the risk of drilling problems.

\section{Keywords}

Al Qarqaf Arch, Ghadamis Basin, Tectonic, Al Hamada al Hamra Plateau, Hydrological Network, Sinkholes, Cenozoic Volcanism

\section{Introduction}

The study area comprises different zones (Figure 1). The Al Hamada al Hamra plateau is essentially a flat area of large dimensions. Using of pertinent Remote Sensing data; DEMs, Lands at mosaics, radar and ground truthing in March 2006 and 2008 were able to substantiate a number of the observations made from the imagery, and also proved vital in enhancing future interpretations made in the area. The imagery was also extremely useful for the field work, not

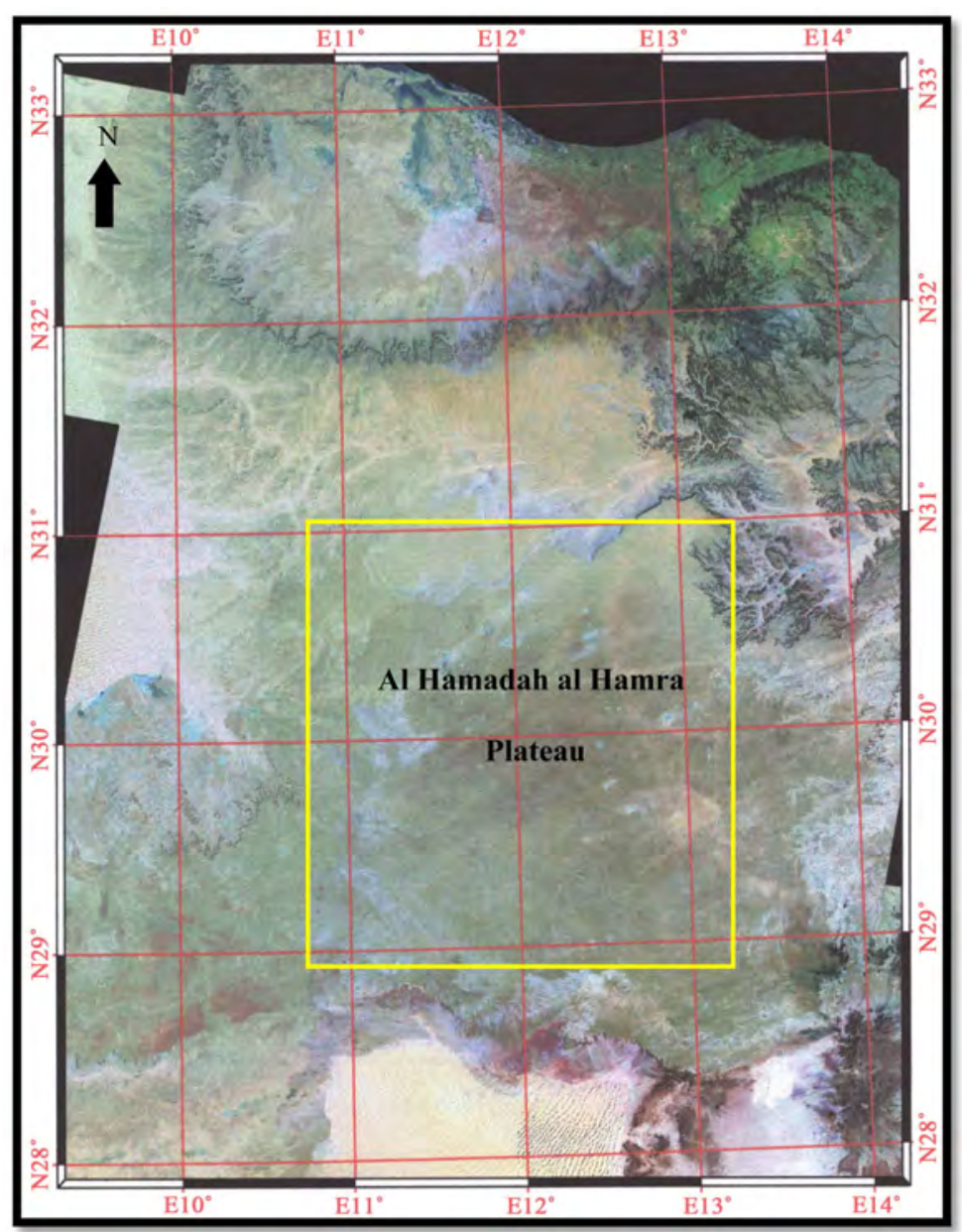

Figure 1. Location map of Al Hamadah al Hamra Plateau and adjacent areas (Landsat mosaic). 
only for location but also in giving a more regional and integrated view of the whole sequence and therefore increasing the understanding of the subsurface equivalent sections. Lineament analysis using all the enhanced remote sensing images has been particularly valuable in determining regional and local patterns that reveal some of the battle deformation history of an area.

Now the satellite data and maps are included into Geographic Information Systems (GIS) where they are geo-coded or at least georeferenced. From the beginning these techniques have been increasingly applied to the exploration process of oil and gas. The information provided by satellite remote sensing and stored in the frame of GISs is huge, and it is now necessary to combine this information with detailed subsurface geology, seismic and other geophysical tools to develop drillable prospect models.

Maybe the methodology has not yet been sufficiently adapted to oil and gas exploration, and the satellite remote sensing imagery alone is insufficient if not correlated with other data and completed with the most recent knowledge and understandings of the various other related earth science disciplines, including fieldwork.

One of the main objectives is to extract the relationship between the deep structural already known of Gazeil-Kabir and Al Hamra oil and gas fields, and to confirm or trust the surface expression of the subsurface structures. A detailed analysis of the Earth Observation Data (EOD) was also undertaken in order to better understand the outcrops of the Paleozoic in the region, with a view to using them as direct analogues in order to assist in the interpretation of the equivalent horizons in the subsurface.

\section{Geological Setting of Al Hamadah Al Hamra Plateau}

By the beginning of the Paleozoic Era, large parts of Libya had been peneplaned as evidenced by Pre-Cambrian rocks wherever exposed. This long period of erosion was general throughout North Africa from the Atlantic Ocean to Red Sea. Paleozoic rocks ranging in age from Cambrian to Permian are exposed in many parts of southern Libya. In south Libya the Paleozoic section grades eastwards from marine to mixed marine-continental facies and finally into a facies that is predominantly continental, so that the south Libya the Paleozoic rocks are mostly continental complexes. A number of transgressive and regressive cycles occurred during the Phanerozoic. Marine incursions during the Ordovician, Silurian, Devonian, Carboniferous, Late Cretaceous and Tertiary reached far south into Libya [1]. Thus, the sedimentary section is dominated by marine shales, carbonates and evaporites in the northern parts of the country and it becomes increasingly clastic southwards (in the Murzuk and Kufrah Basins), with an increasing frequency of stratigraphic hiatuses [2].

The Ghadamis Basin contains Infra-Cambrian which is assumed to represent rocks of Late Proterozoic age, Palaeozoic and Mesozoic sediments that non-conformably overly an igneous and metamorphic basement complex. The cover sediments range in age from Infra-Cambrian to Late Cretaceous and are 
nearly 21,400 feet thick [3]. In the basin, several cycles of sea-level fluctuations have been described that correspond to tectonic episodes and significant climate changes, particularly during the Palaeozoic [4]. Hydrocarbons in the Ghadamis Basin are produced from several Palaeozoic horizons (Table 1). The main producing horizons are the Silurian (Acacus Formation) in the north and central parts, and the Devonian (Tadrart Formation) in the southern and central parts, with combination traps in the southern and northern parts of the basin, structural traps in the central part, and minor stratigraphic traps in the western part of the basin [5]. The source rocks are mainly Silurian shales, with Devonian shales. The Silurian-Devonian sequences are important both as reservoirs and source rocks.

Al Qarqaf Arch, which separates the Ghadamis and Murzuk Basins, represents an interesting problem in the structural and stratigraphic evolution of North African Basins. The Arch was periodically a high in Early Paleozoic times, and remained as a discontinuous positive feature. The stratigraphy and structural setting are quite varied on both sides of Al Qarqaf Arch. The Lower Carboniferous (Mrar Formation) is the only Formation from the Carboniferous sequence that will be dealt with due to its importance as a reservoir in some parts of the Ghadamis Basin (Table 1). Data made have been integrated into this analysis. A detailed description of the geology of the whole Paleozoic system is not within the scope of this study.

Table 1. Formation names related to ages of the Paleozoic rocks in Ghadamis basin.

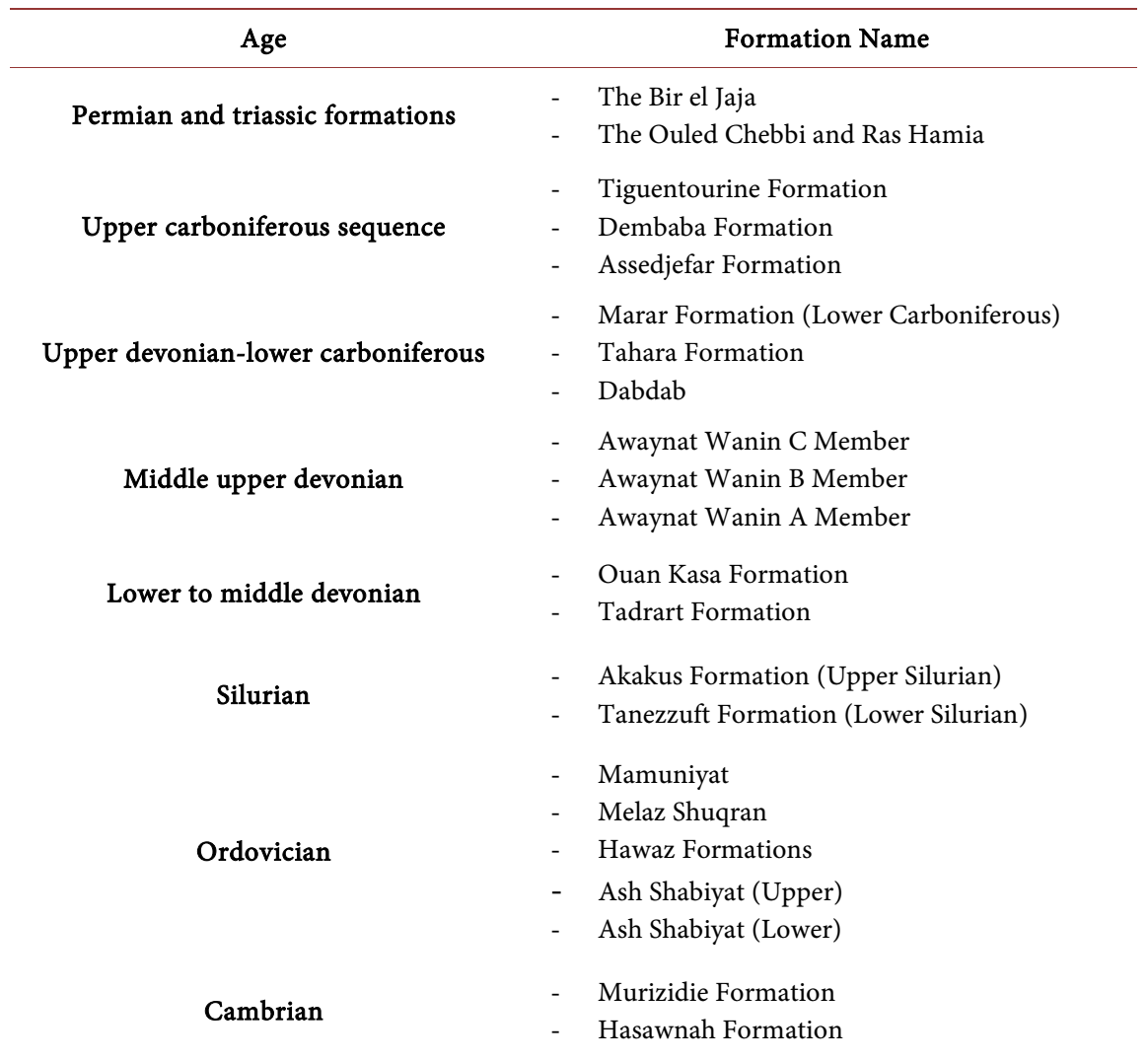




\section{Mapping of Litho-Stratigraphic Units Using Remote Sensing}

\subsection{Data Used}

Landsat TM, SRTM DEM, ERS-2 SAR scenes and Google-Earth views were used and interpreted for geological structure at different scales. The remote sensing data set comprises digital enhancement of Landsat TM and Radar images to map surface structures.

\subsection{Image Characteristics of the Units}

The objective of the surface condition map is to provide a preliminary evaluation of the surface conditions in view of the preparation of the field operations. The most common surface expressions were defined on the surface condition map: sand dune (1\&1+6), Sabkha (9), escarpment (3), rock types $(4,5,7 \& 8)$ and the drainage $(6 \& 1+6)$, especially its density, is important part of the surface conditions (Figure 2).

Most of the central basin is a flat plateau and there is no rough terrain, except for some areas that were affected by trends of disturbed topography (e.g. Gzeil area, Wadi Tahara trend). The red colour, which covers the plateau, is related to the erosion of carbonates of Upper Cretaceous or Lower Paleocene age. The terrain conditions of the northern and southern borders are characterized by the main escarpments of Nafusah uplift in the north and Al Qarqaf arch in the south (Figure 3). West of the Hamadah Al Hamra several successive escarpments

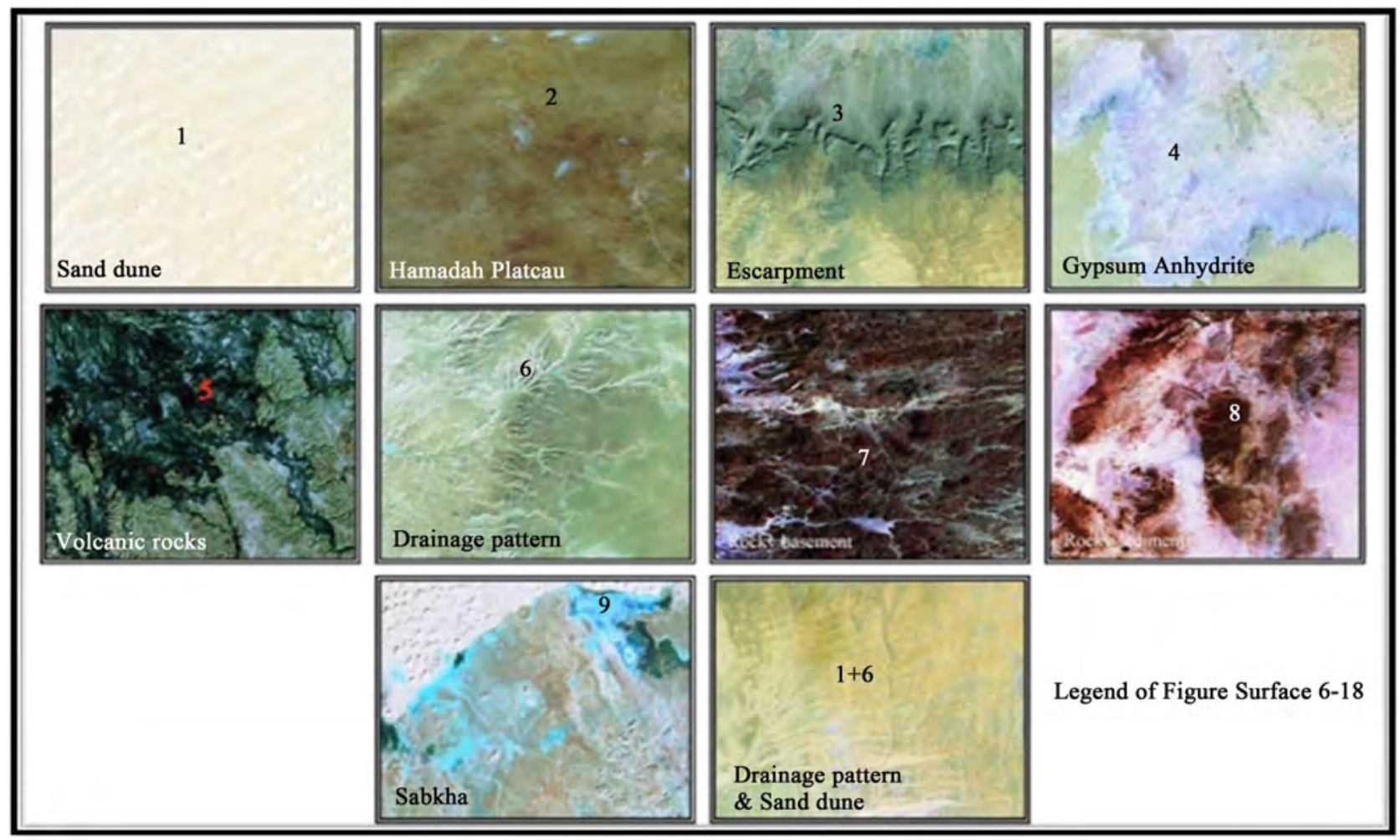

Figure 2. Main ground surface aspect classified over the area. 


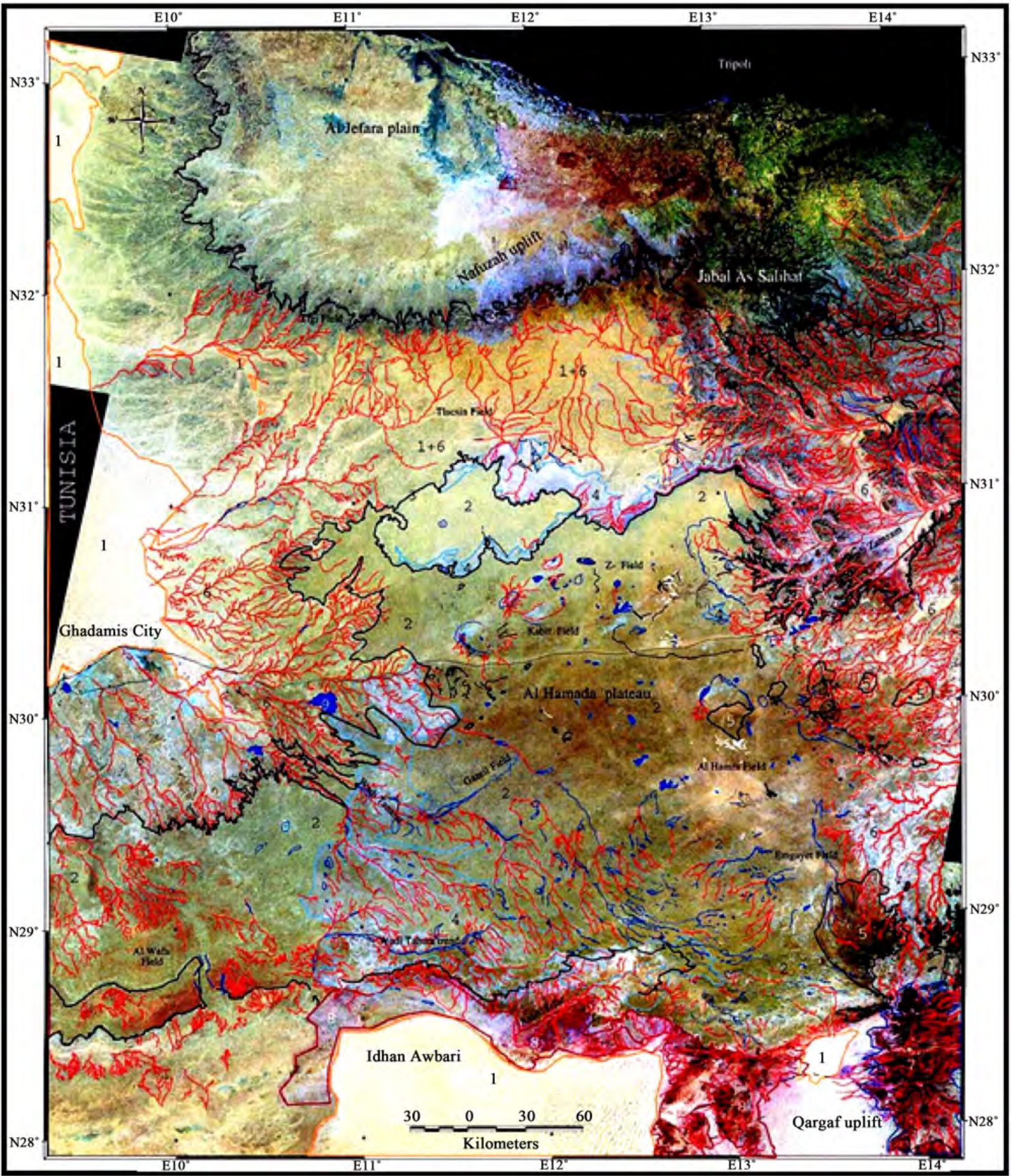

Figure 3. Terrain analysis (surface aspect) and drainage pattern of Ghadamis basin and adjacent areas. According to Figure 2, of the classified main ground surface.

complicate the seismic acquisition and are detrimental for seismic quality. Large Quaternary covers usually correspond to Ergs, and also comprise the Idhan Awbari and Murzuk sand seas. Most of the sand dunes are abundant in the 
southern and western border of Ghadamis basin and are difficult to access. The sand dunes in the southern part are limited by the escarpment and the shape of sand dunes is elongated. It looks as a flat area where the sand dunes are more dense and scattered due to the main direction of wind coming from the NW. The south-western regions are mainly characterized by Sabkhas and less dense drainage network compared to the eastern border (Figure 3), due to low elevation and low erosion. The presence of salts is generally manifested by the appearance of moisture or a darker tone that distinguishes sabkhas from other areas. Even when a sabkha becomes dry, the moist appearance is retained. The characteristic features of these sabkhas are small size in the central part of Ghadamis basin.

The north central and south western parts of the basin are characterized by presence of evaporite rocks (Gypsum), clearly shown by the spectral signatures forming white-blue colour on the Landsat TM colour composite mosaic.

\subsection{Update the Ancient Geological Map}

New geological map: Our new geological map is presented in (Figure 4), comparing with the differences of the ancient map (Figure 5).

\section{Tectonic Analysis}

\subsection{Evidencing Anticlines}

The Al Hamadah al Hamra plateau is flat (Figure 1) and most of the surface corresponds to outcropping Paleocene limestone, except in the borders all around, made of late Cretaceous limestone (Figure 6). In the north-northwest border, the plateau comprise large surfaces of Maestrichtian limestone, possibly a consequence of the fact that in this region the dips are to the south, the border being slightly uplifted when approaching the Nafusa arch situated more to the north. The weathering-erosion couple might have been more efficient than in lower elevations, resulting in removal of the Paleocene. The Paleocene-Maestrichtian boundary is almost straight in this northern limit and trends $\mathrm{N70} 0^{\circ}$, the strike of the layers gently dipping south-southeast. The Campanian rocks are outcropping more to the north, outside the cuesta forming the plateau boundary, in deep valleys formed by regressive erosion. The eastern margin of the plateau is also dominated by regressive erosion rending the Paleocene-Maestrichtian contact complex in map view. In the southern margin, the plateau's border is a $\sim \mathrm{E}-\mathrm{W}$ striking cuesta on top of which the Paleocene outcrops, except in its western part dominated by the drainage system of the regressive El Marar valley, eroding as deep as the Palaeozoic. Our mapping has evidenced gentle anticlines in the Al Hamadahal Hamra plateau, numbered A1 to A20 in (Figure 6). The clues for these folds are: 1) layer traces forming fold closures, 2) drainage anomalies, 3) folded topographic surfaces, 4) outcrops of Maestrichtian rocks amidst Paleocene layers. 


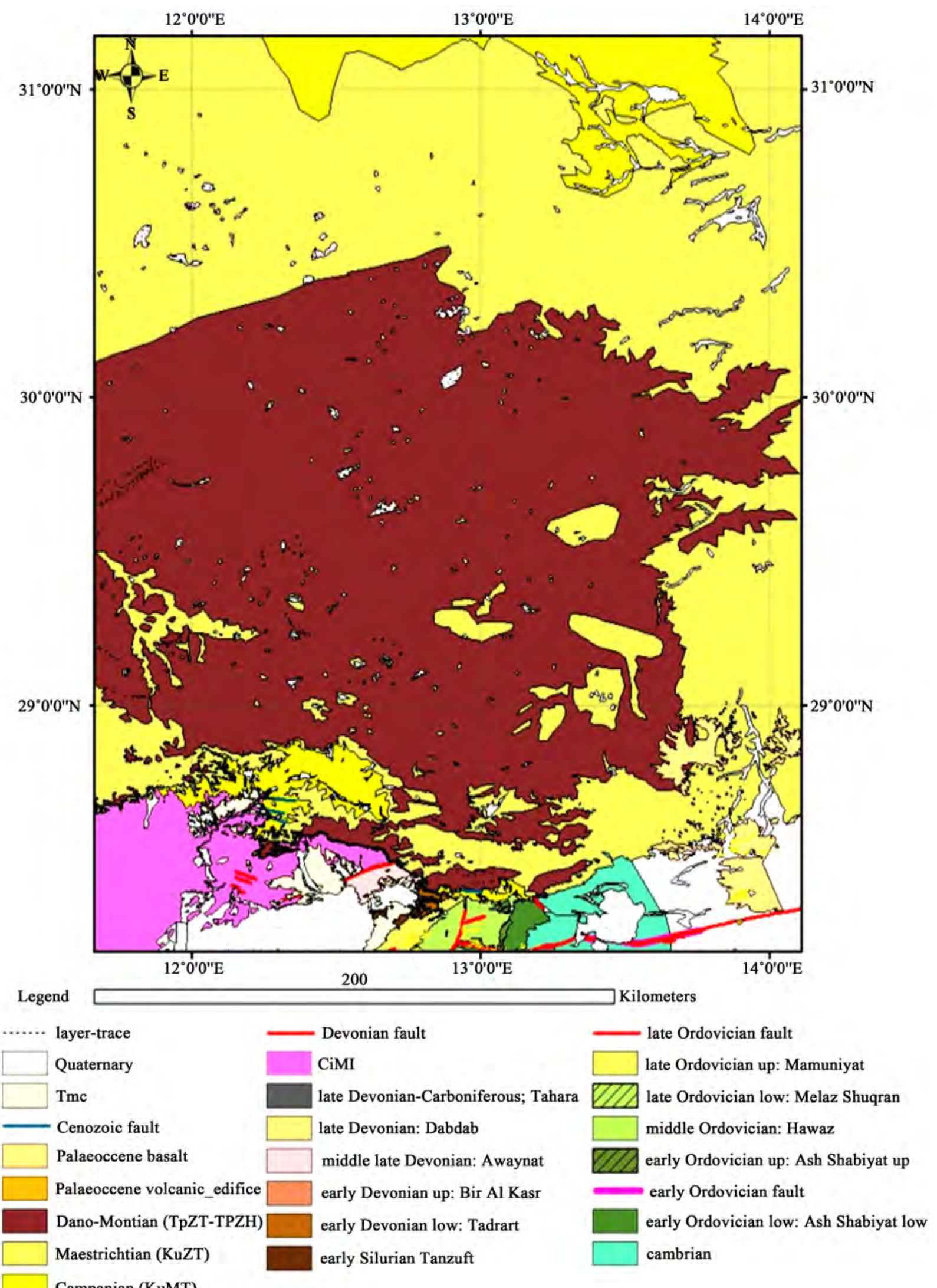

Figure 4. New geological map by using GIS, mapping from Landsat TM5. 

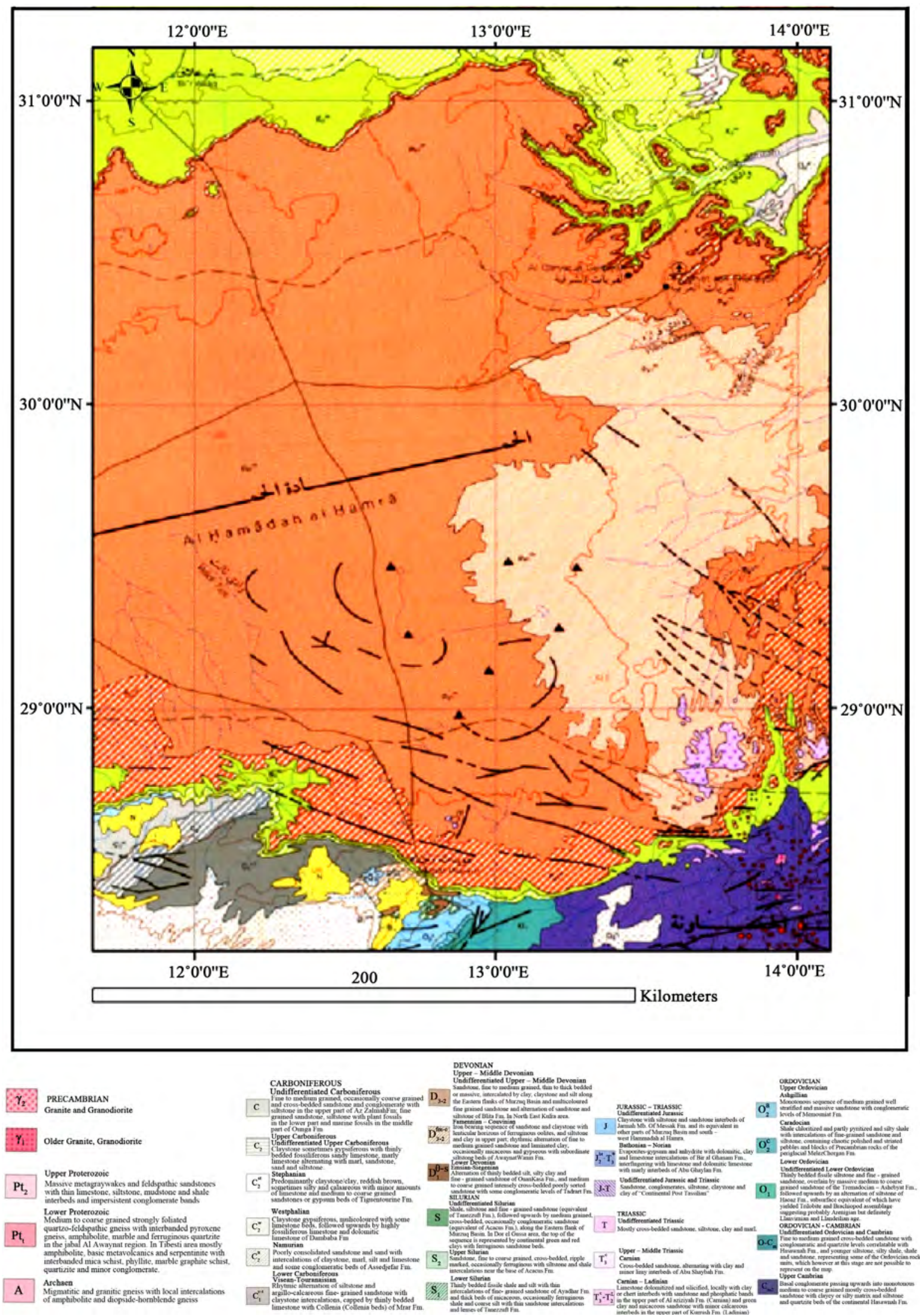

Figure 5. The ancient geological map, 1:1000,000 [6]. 


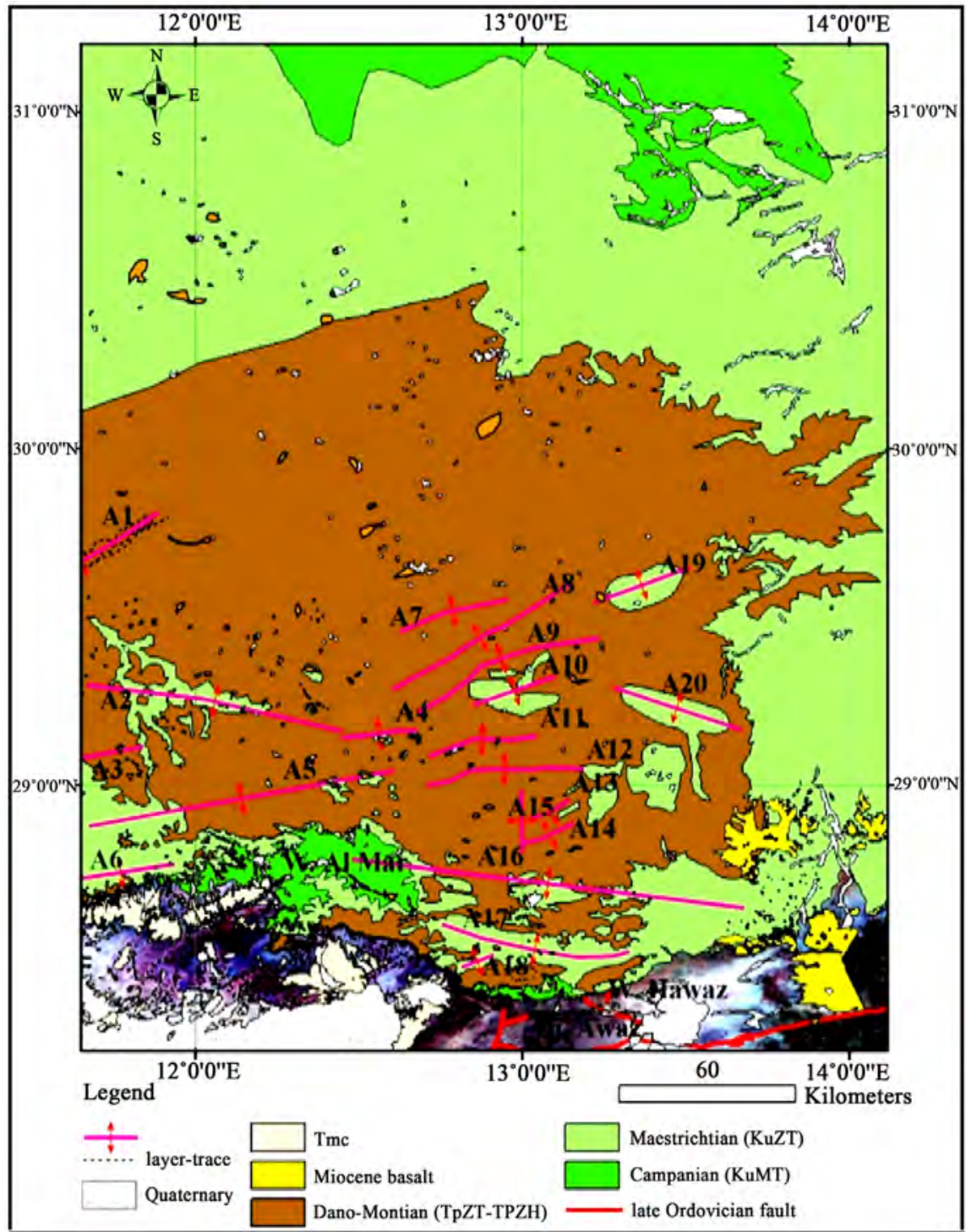

Figure 6. Mapping of Al Hamadahal Hamra plateau showing anticline axes A1 to A20.

\subsection{Fold Closures of Layer Traces}

Anticline A1 (El Gziel anticline) is already known (Figure 7). It is well exposed in the optical, DEM and radar images. The layers traces of the Paleocene underline the fold closures at each end, and dips on the sides are in opposite directions. Erosion has occurred but not deep enough to expose the Maestrichtian in outcrops. The Paleocene core of the fold forms a small dome (d on DEM image) slightly higher than the nearby flat plateau. This means the fold was formed after the Paleocene, but quite recently because the erosion in the dome has not reach the Cretaceous.

\subsection{Maestrichtian Outcrops}

Inside the large flat surface in the heart of the plateau occupied by Paleocene rocks, we have also mapped isolated outcrops of Maestrichtian rocks (A10, A16, 

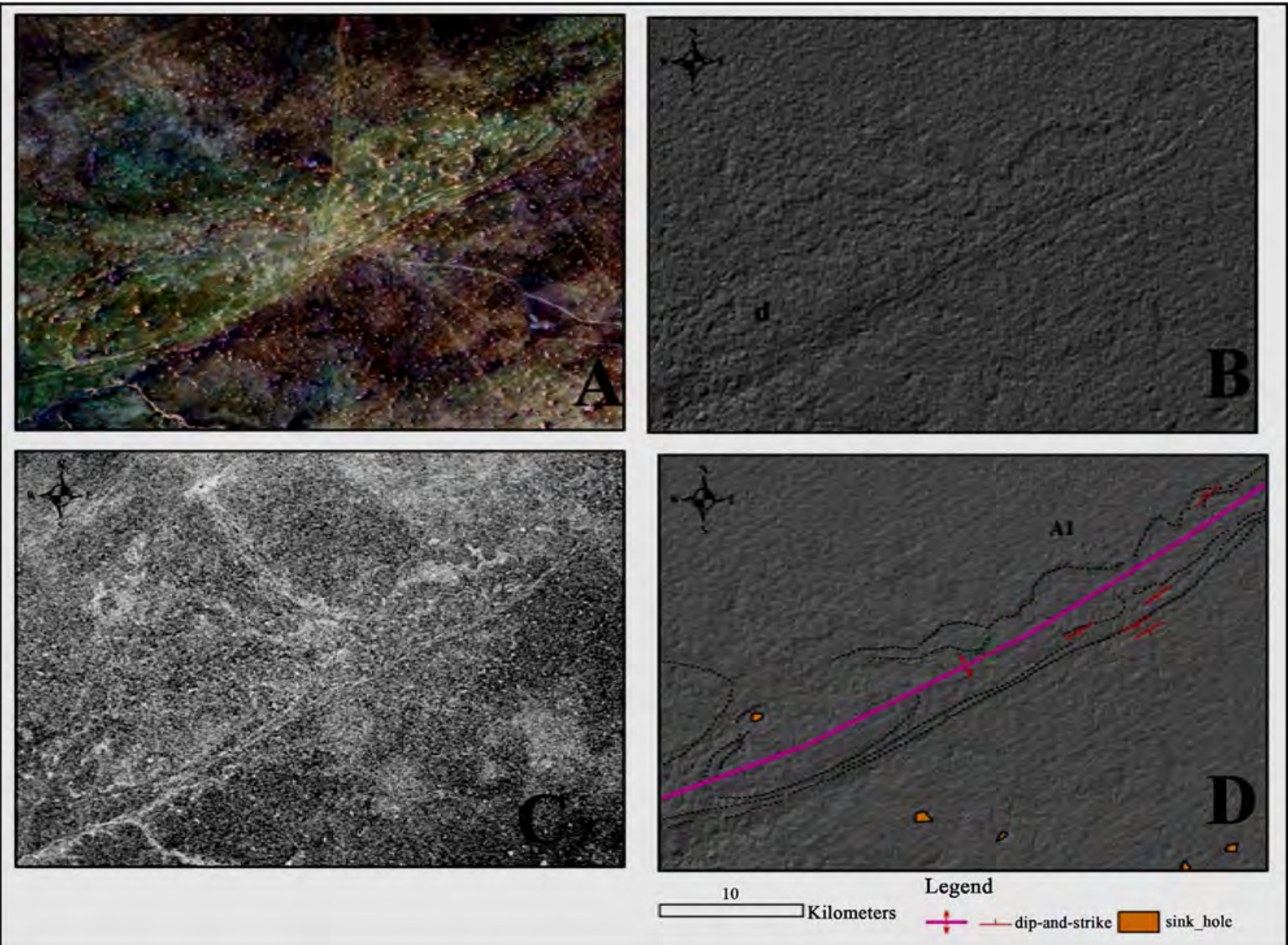

Figure 7. (A) Landsat image; (B) SRTM DEM shadowed image; (C) ASAR negative image; (D) Mapping showing layers traces and anticline axis, over the DEM image.

A17, A18, A19 and A20, (Figure 6). Dips and strikes could not be measured in the sides of these folds. For instance, in the A1 surface, the Maestrichtian is recognized on the basis of the spectral signature which shows up in light blue yellowish colour on the Landsat colour composite image of (Figure 8), also characterized by a smooth texture. On the same image, the Paleocene is recognized by brownish patches. Because the boundary is not distinct, the Maestrichtian outcropping there should correspond to the top layers of this unit, situated almost at the stratigraphic upward transition with the Paleocene. The surface is strictly flat and horizontal as shown by GDEM and SRTM images. The map in this topography must correspond to a gentle anticline with axe striking $\mathrm{N} 65^{\circ}$.

Another example is fold A2, which lies almost E-W along the southern border of the plateau (Figure 9). A large outcrop of Maestrichtian rocks, forming light bluish surfaces on the Landsat image, and also visible on the SAR ERS image is almost surrounded by Paleocene deposits. This is visible also from Google-Earth view17 (Figure 9(C)). The topographic surface is almost flat, a little depressional, as shown by the DEMs. The fold axis changes in trend from WNW to ENE. The anticline is gentle, the dips in its sides being almost horizontal. 


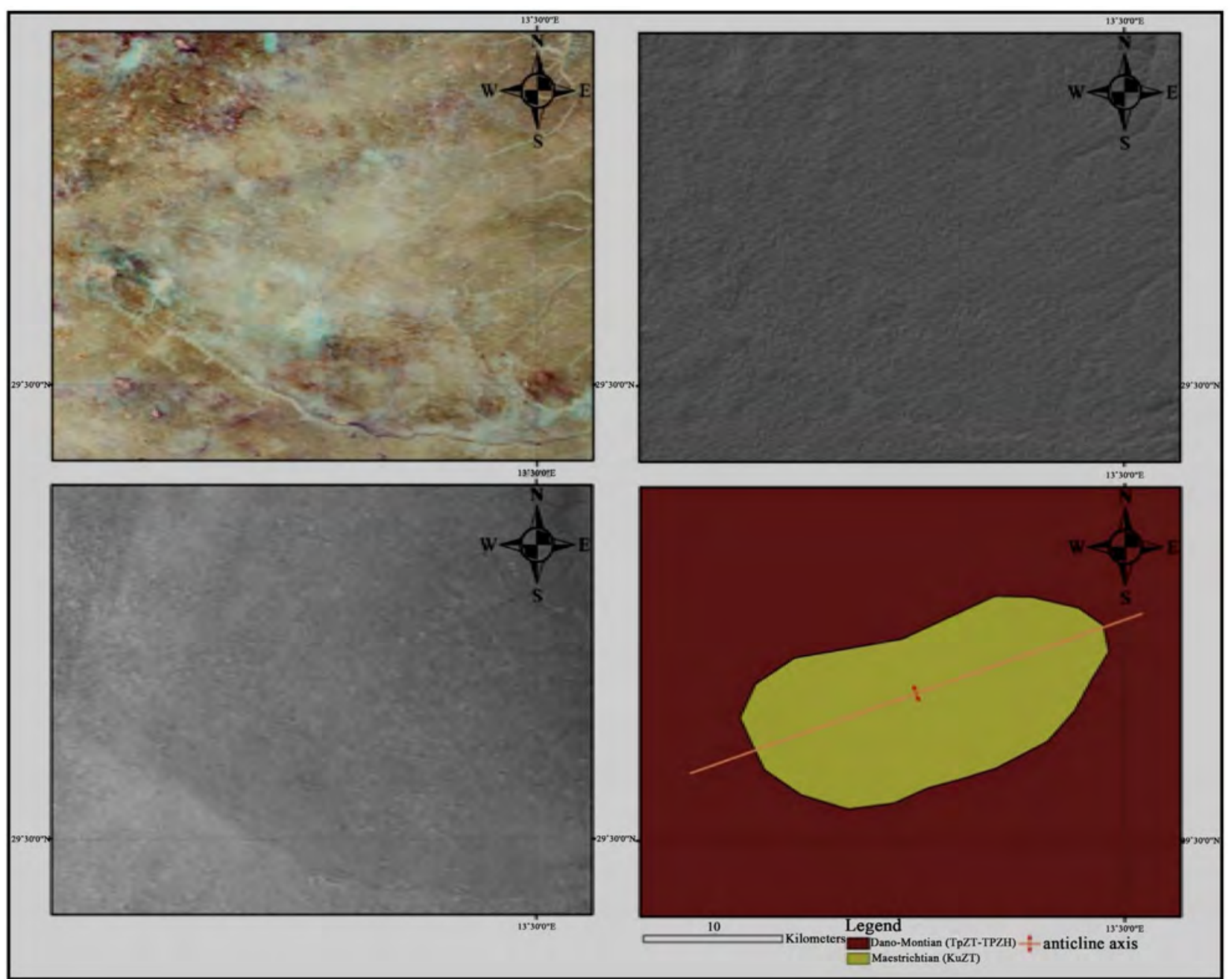

Figure 8. Left top (Landsat image); Right top (SRTM shadowed DEM); Left bottom (GDEM elevation image); Right bottom (geological map).
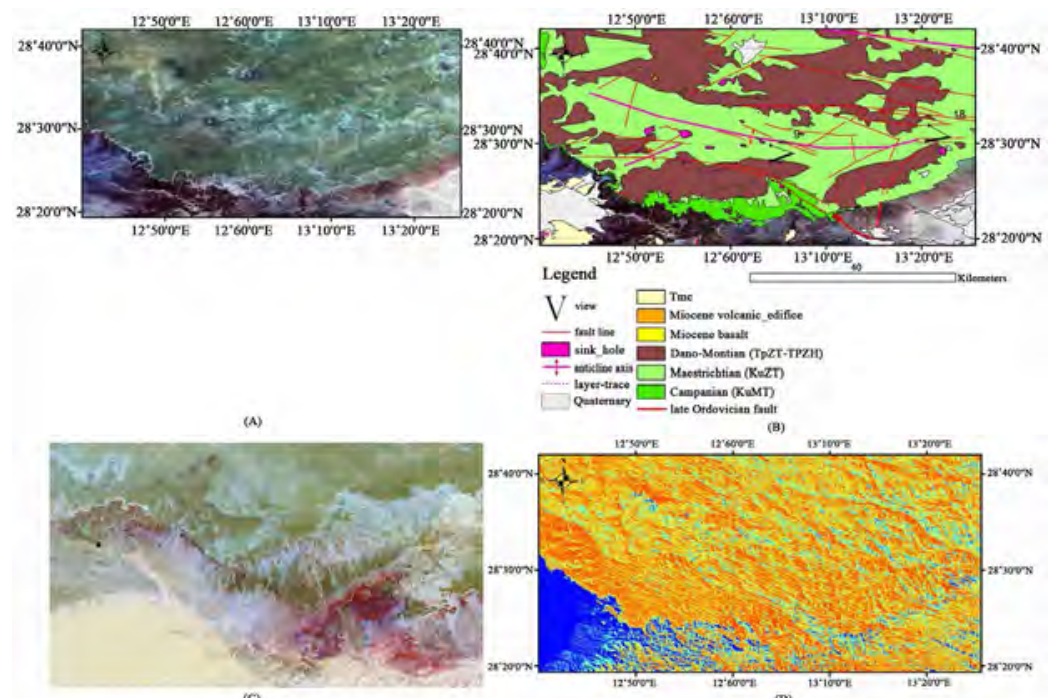

Figure 9. (A) Landsat image; (B) Our new geologic map; (C) Google-Earth oblique image from point of view 18 on map B; (D) DEM in hypsometric colours. 


\subsection{Folded Topographic Surfaces}

In places $\mathrm{A} 3$ to $\mathrm{A} 10$ in (Figure 10) the topographic surface is folded forming elongate discrete hills that correspond to anticlines in conform morphology. This is shown by SRTM shaded DEMs computed with a small $\left(10^{\circ}\right)$ angle of illumination from the NW. This peculiar possibility of observation is due to recent availability of precise DEMs and of software permitting artificial illumination from any direction, especially almost horizontal elevation.

The axes of anticlines are not straight, spanning from NE-SW to E-W. The A15 anticline axis trends are N-S. The dips in the sides are not really measurable in the field, yielding a few degrees. According to the shaded DEMs, anticlines A7, A8, A9 and A12 are asymmetrical, their southern side steeper than the northern. In locations A21, A22, A23 it is possible to draw anticline axes on the basis of irregularities of the topography of the structural surface, but the shape is not pronounced. The anticlines are generally poorly eroded, but fold A8 as well as A11 are cut by N-S valleys, deeper at the fold axe, similarly to the pattern of anticline A2 (Figure 11), testifying for a recent uplift.

\subsection{Topographic Cross-Section}

A topographic cross-section (Figure 12) in the area of anticlines affecting the topographic surface shows particularities of their morphology. The difference in elevations between the plateau and the fold summits is of the order of $20 \mathrm{~m}$. The anticlines are asymmetric, with southern side shorter (Figure 12). The age of these anticlines should be recent for they are almost not eroded.

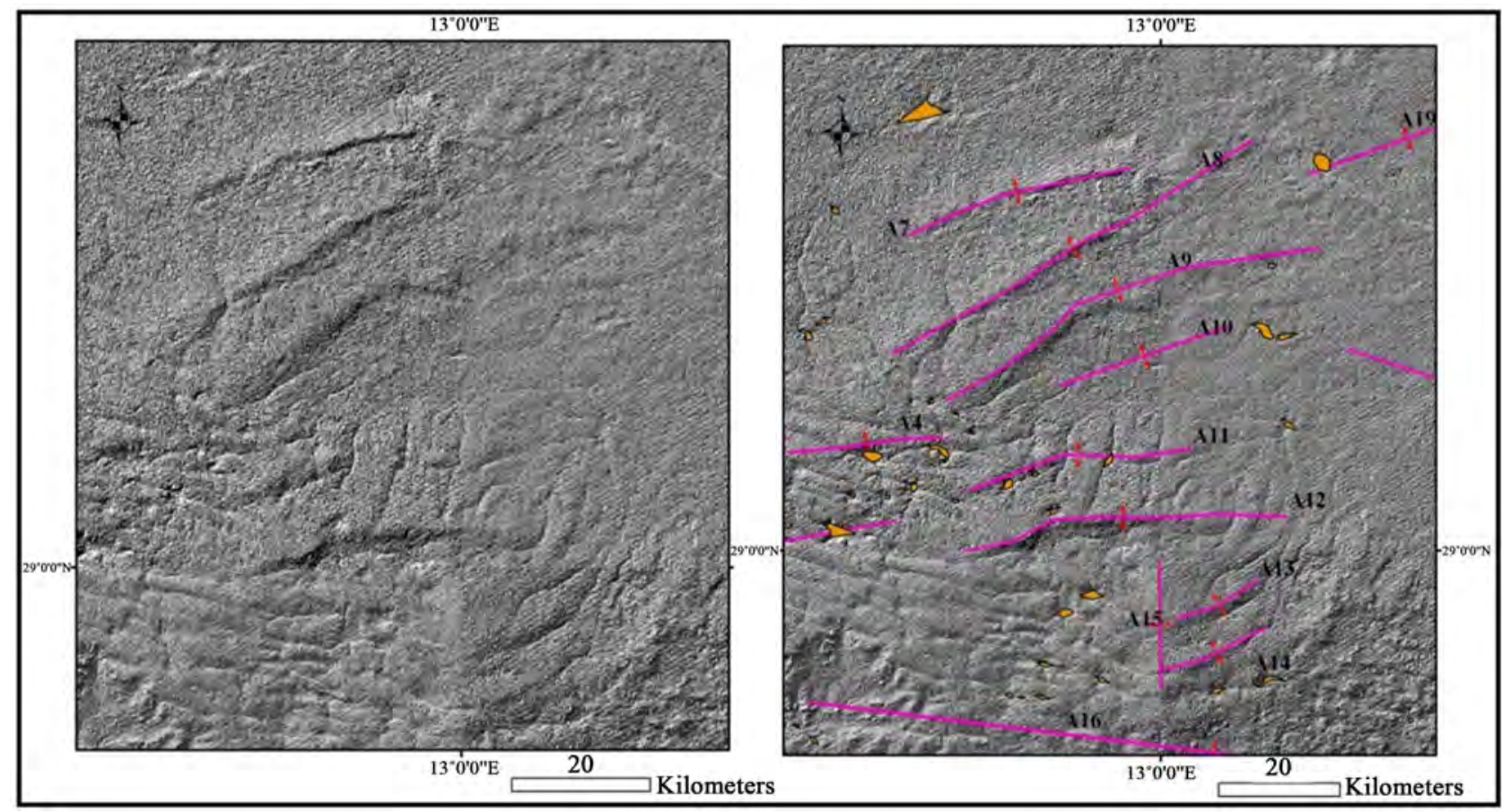

Figure 10. SRTM shaded DEMs, topographic surface is folded forming elongate discrete hills that correspond to anticlines in conform morphology. 


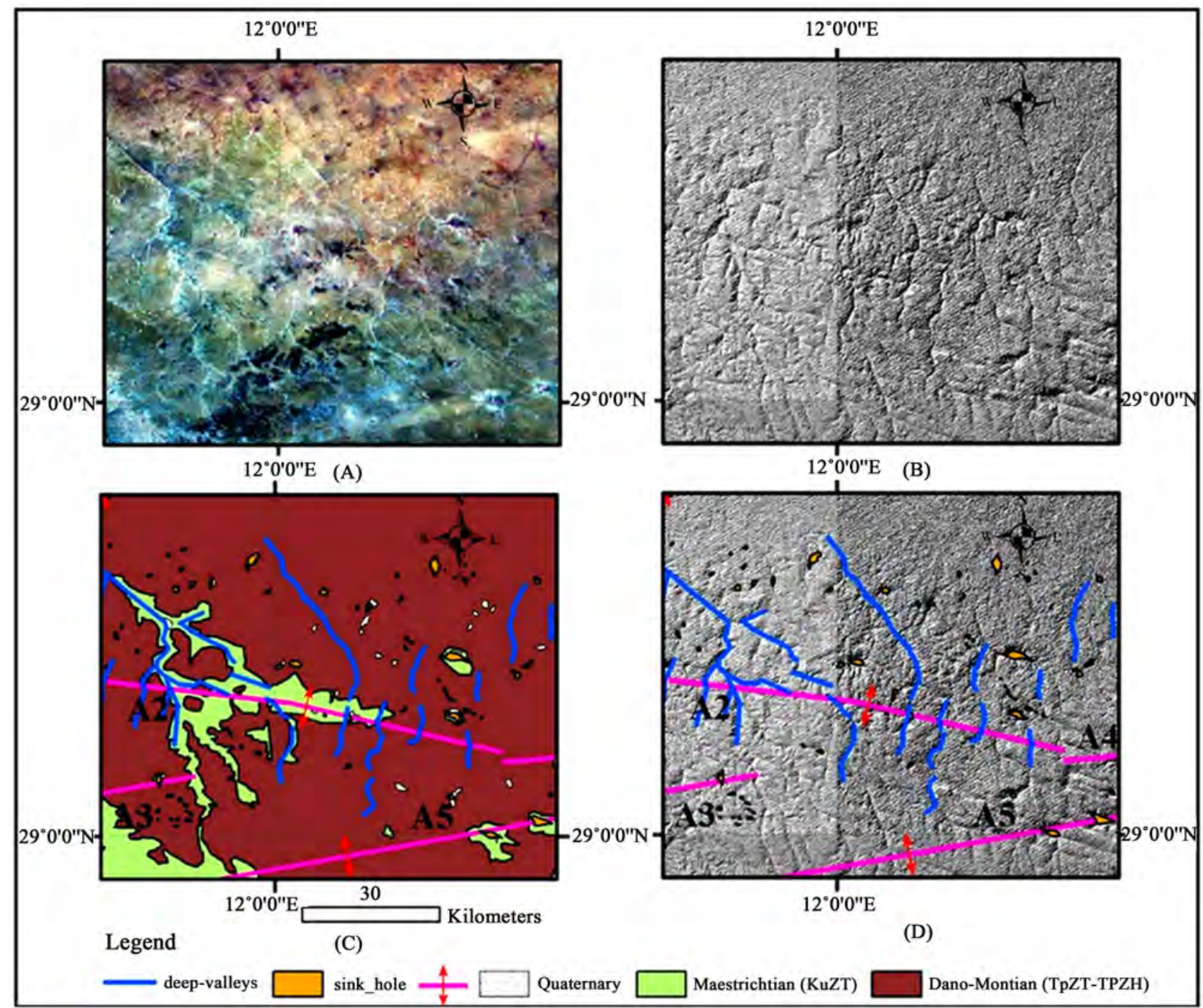

Figure 11. (A) Landsat image; (B) Mosaic of SRTM DEMs shadowed images (illumination from NW); (C) Interpretation of DEMs; (D) Geological map.

\section{Hydrologic Network Anomalies}

\subsection{Data}

The hydrologic network (Figure 13) is given by a database, which we have completed in places from the analysis of Landsat imagery. The $1^{\text {st }}$ Stahler order segments are generally not represented. Most of the plateau surface is an immature, multi-basinal to karstic network including sinkholes [7]. The drainage basins in the north and east belong to the Mediterranean basin, while the systems in the south end into local sebkahs. All along the eastern border of the study area, the system is contorted, related to drainage linear anomalies. In the south-eastern corner, the pattern is centrifugal, due to the volcanic Jabal Al Harouj massif. In the south-western corner the system is parallel to contorted. Analysis of drainage system follows the method of [8]. This drainage system shows different types of drainage anomalies. 


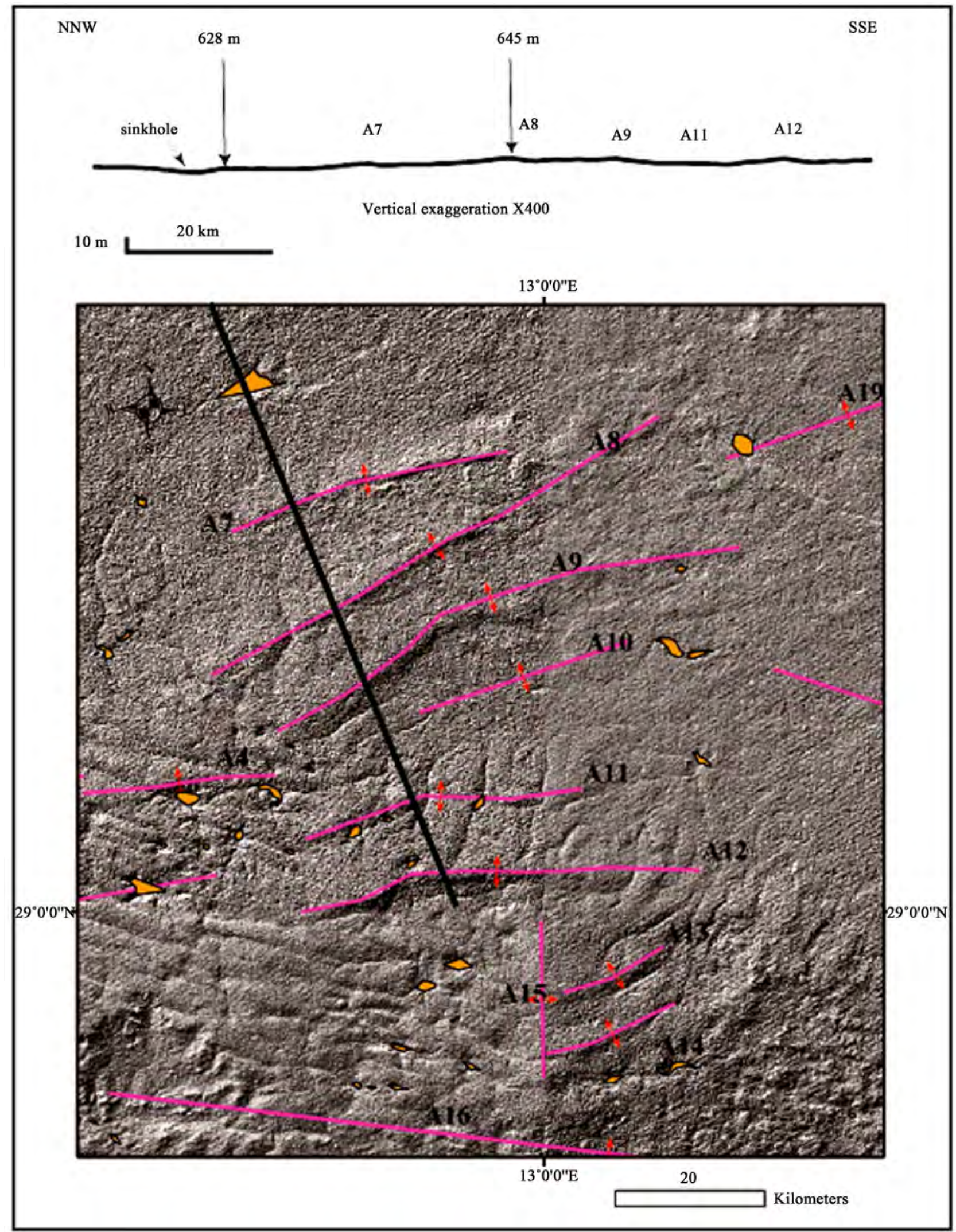

Figure 12. A topographic cross-section in the area of anticlines affecting the topographic surface shows particularities of their morphology. 


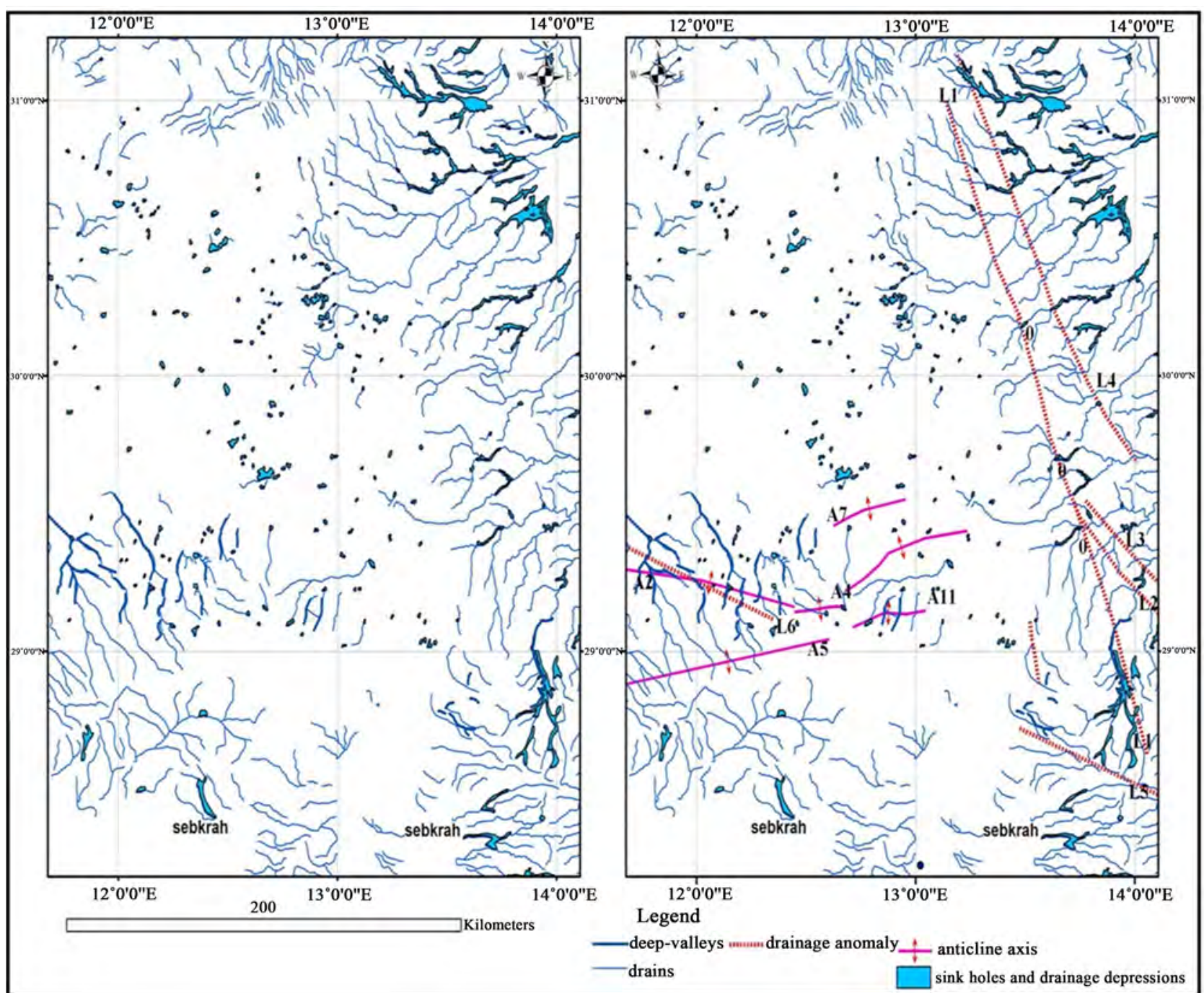

Figure 13. Drainage system shows different types of drainage anomalies. All along the eastern border of the study area, the system is contorted, related to drainage linear anomalies. According to the shaded DEMs, anticlines A7, A8, A9 and A12 are asymmetrical, their southern side steeper than the northern one.

\subsection{Types of Drainage Anomalies}

\section{1) Incised valleys}

Incised valleys; in the area $\mathrm{A} 2$, valleys are deeper than in most places of the flat plateau. This pattern argues for the presence of anticline A2 (Figure 11). This incision of valleys might be due to quite recent local uplifts of parts of the plateau, inducing deeper river erosion. These features are also related to occurrence of Maestrichtian outcrops surrounded by Paleocene, not only in the bottom of the valleys but also on the nearby plateau (Figure 11(D)). Incised valleys are also clues for interpreting anticlines A4, A7 and A11 (Figure 13).

\section{2) Arc shape in map view}

Arc shape in map view; the deep valleys of anticline A2 have an arc shape in map view, centred on the valley (Figure 13). This is true also for deep valleys crossing anticlines $\mathrm{A} 5$ and A11. 
These arc features, which were mentioned on a more general basis by [9] are found in location A24, and may be used to interpret an anticline axis, which would end northward into similar arc-shaped drains.

\section{3) Confluence of tributaries}

Confluence of several tributaries at the same point is known to be a drainage anomaly. Those marked 0 in (Figure 13) are aligned and can be considered as part of a lineament named L1.

\section{4) Aligned sharp changes in talweg direction}

Aligned sharp changes in talweg lines; Talweg traces are generally not straight and may comprise local sharp changes in direction. When the sharp changes are aligned, it is possible to consider those lines as drainage anomalies. Interpreting lineaments L2, L3 and L4 are based on such anomalies.

\section{5) Parallel talwegs}

Parallel talwegs are the valleys running parallel to each other along noticeable distances are also linear anomalies. Lineament L5 is based on such a feature.

\section{6) Tributaries along only one side}

Tributaries on only one side of linear drain segment. Along southern end, lineament L1 is interpreted to run along eastern side of a NNW-SSE group of aligned wadis, whose tributaries are all issued from the western side.

\section{7) Structural valleys}

Structural valleys, most parts of the drainage network lines are the result of fluvial erosion, but some segments correspond to structural valleys, mainly formed along fault lines by tectonic throw with eventual vertical component. This is the case in site 8 (Figure 14(A) and Figure 14(C)), where an arc-shaped valley segment follows a fault well identified by its scarp (F) and differences in elevation of the plateau on each side of the valley (B). In the field at site 4 (Figure 14(D) and Figure 14(E)), we have observed that the valley forms a flat depression $400 \mathrm{~m}$ wide, filled with a poorly sorted gravel deposit, with no evidence of wadi course contrarily to true eroding wadis existing in the plateau area. Another example of structural valley is shown in (Figure 14(D) and Figure $14(E)$ ). The valley is straight and follows an alignment of tiny sinkholes, to end finally SW-ward into a larger sinkhole. To explain these structural valleys, we interpret that late Cretaceous to Paleocene limestone layer successions of the plateau, lying dis-conformably over the Palaeozoic detrital series, may behave as a slab which breaks in fragile style under regional extension, and fault lines tend to open accompanied by collapse, forming a network of structural valleys.

\section{Tectonic Lines (Lineaments)}

\subsection{Approach}

The lineaments determined from drainage network anomalies but not forming a continuous line in the landscape can be regarded to be related to hidden deep-seated rock discontinuities, but not necessarily [10]. Given their length (L1, $273 \mathrm{~km}$; L2, $90 \mathrm{~km}$; L3, $71 \mathrm{~km}$; L4, $181 \mathrm{~km}$; L5, $83 \mathrm{~km}$; L6, $230 \mathrm{~km}$ ), they may be 


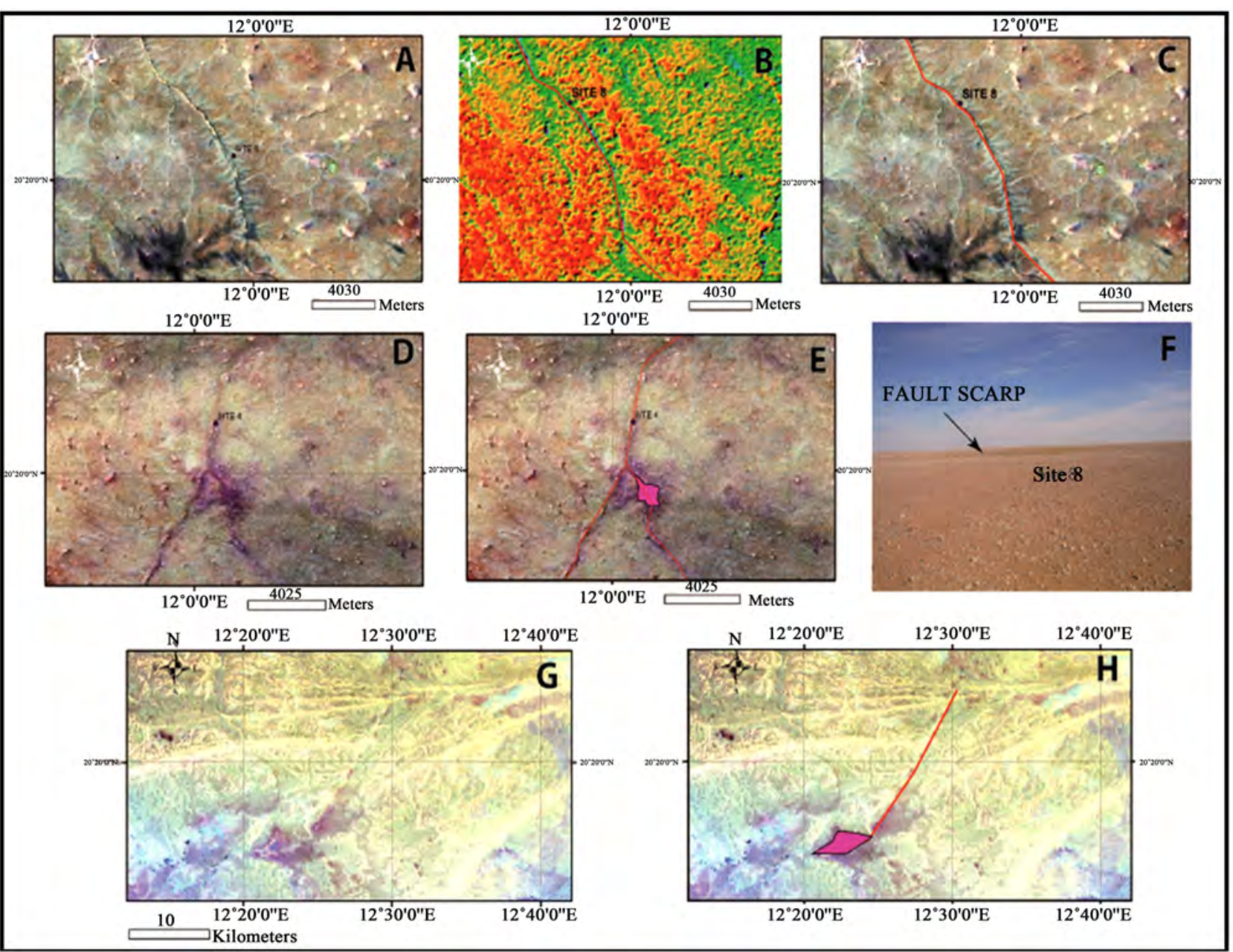

Figure 14. Examples of structural valleys. A, B, C and F: site 8. (A) Landsat image of site 8; (B) GDEM image of site 8 in hypsometric colours; (C) Mapping of site 8over Landsat image; (D) Landsat image of site 4; and (E) Drawings corresponding; (F) Field view in site 8, looking NE; $(\mathrm{G})$ and $(\mathrm{H})$ Landsat image and fault interpretation along a straight succession of tiny sinkholes along a structural valley.

related to any discontinuities affecting the structure in depth, such as folding, important disconformities, changes in thickness of units, changes in tectonic style, etc. The other tectonic lines that can be observed are shorter but directly visible in the landscape. Our approach for identifying fractures is based on the concept that among the numerous more or less rectilinear lines that are found in the imagery (roads, trails, pipe lines, seismic lines, layer traces, valleys, boundaries between rock units, dikes, etc.), the tectonic lines such as joints and faults displace layers or have effects on the drainage system and the morphology. The DEM, radar and optical images are consequently the privileged data that are convenient for studying drainage, morphology, unit boundaries and layer traces. We started the mapping with the SRTM and GDEM shadowed DEMs, and completed our observations with the SAR ERS and ASAR images, and finally the Landsat data. All the fracturing identified corresponds to individual lines observed on the imagery, straight or regularly curved, frequently paralleling each other. Among the lines drawn in (Figure 15), those which show scarps, clear 


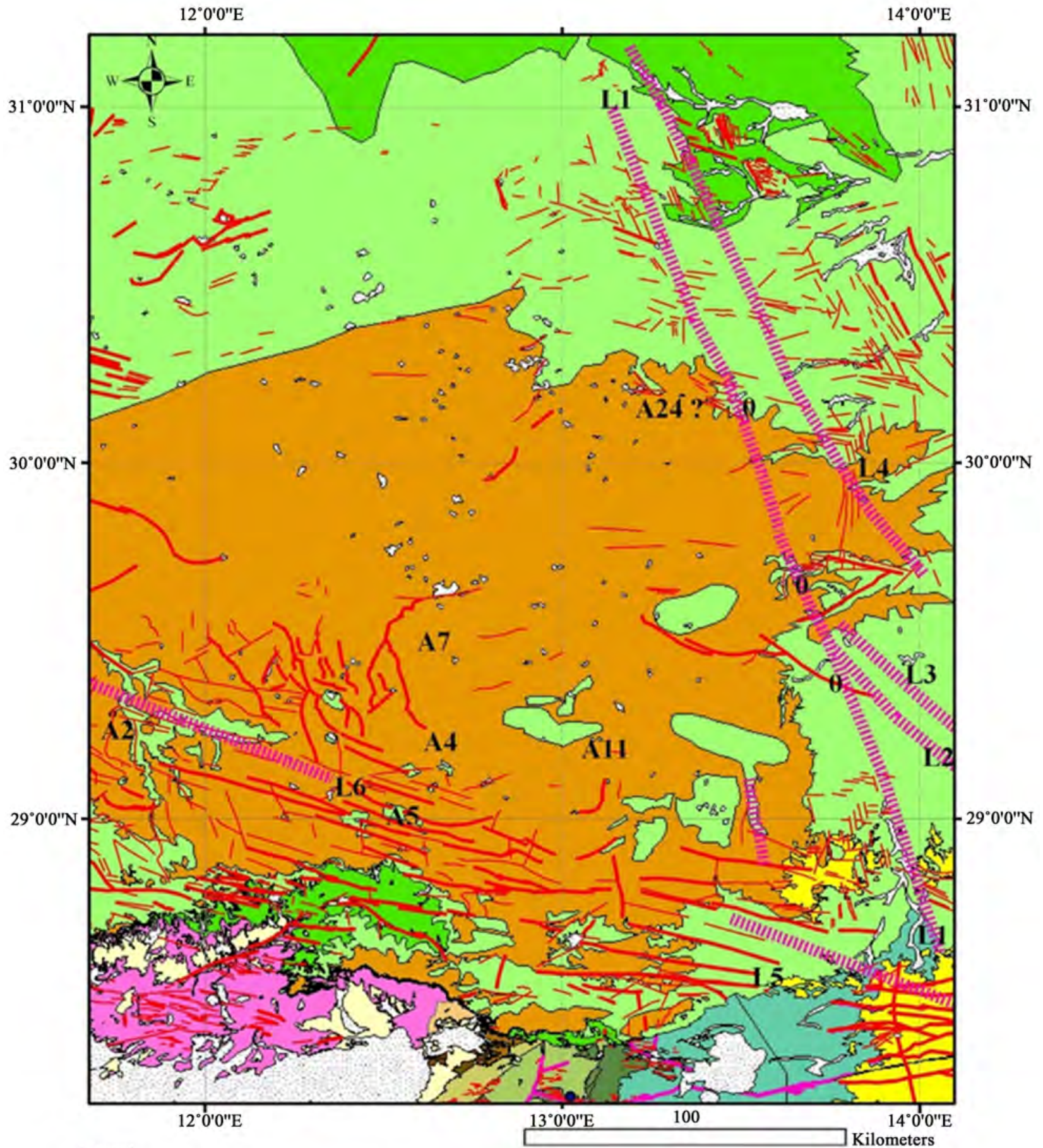

Legend

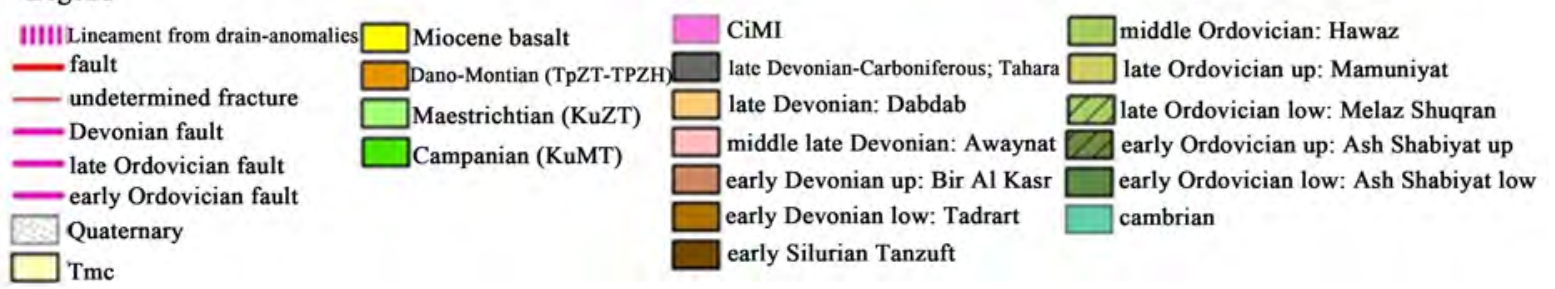

Figure 15. Three families of faults (and joints?) can be observed both in the Mesozoic-Cenozoic cover, the basement outcropping in the south, and the Miocene basalt in the south-eastern corner of the map. 
displacement of layers, drainage anomalies such as structural valleys and sinkhole alignments in the imagery or in the field, are faults. In the special case of the faults also are lines visibly displacing the structural surface of the plateau, at the scale of mapping $(1 / 100,000)$. The displacements that have to be observed to map faults are sometimes hidden or too small to be sensed, especially from the imagery. We also interpret that such lines of great lengths (more than a few kilometres) characterize fault. The others remain more fractures, most of them being simple joints.

\subsection{Mapping}

The mapping all over the study area has resulted in the identification of a few lineaments, a great number of faults and undifferentiated fractures (Figure 15), much more than in previously existing maps, from which however all the faults previously mapped were not identified. In the middle of the plateau, the density of such lines is poor, but on the contrary they are frequent and short in the north, and become abundant and longer to the south, when approaching the $\mathrm{Al}$ Qarqaf arch. The fractures can be sorted in families corresponding to strike directions. The most frequent is the ESE strike, but there are E- and $\sim \mathrm{N}$-striking families. In places, the lineaments are coincidental with fractures. This is the case for the NNW-SSE trending L1 and L4 lines, strictly paralleling faults located more to the east. They separate two regions, one to the east, affected by NNW-SSE fractures paralleling to the Hon graben (Hon graben tectonic province?), and the other one to the west where WNW-ESE lines are dominant. WNW-ESE trending lineaments L5 and L6 are aligned and trend parallel to numerous fractures in the same direction, some of them superimposed to the lineaments, which justifies considering that they constitute a unique $430 \mathrm{~km}$ long L5 - L6 lineament. The faults we have observed in the field have, small throws (a few tens of metres), mainly vertical. They don't sufficiently displace the compartments to form boundaries between litho-stratigraphic units.

\section{Volcanism and Tectonics}

\subsection{Approach}

In the southeast part of the study area, basalt and Phonolite outcrops are generally (geological map of Libya at 1:1,000,000) attributed to the post Eocene volcanism of central Libya, possibly Miocene to Quaternary. They also are considered to be coeval with the volcanic rocks of the Al Haruj al Aswad massif located more to the east. According to [11], the volcanic eruptions of the Al Haruj al Aswad massif span from the early Pliocene to the late Pleistocene. Did the magma have reached the surface through the opening of tectonic features? To answer on this question, we have used an approach based on observations of [12], which establish that, the morphology of volcanic edifices in plain view preserves the overall shape of open tectonic features. The volcanic venues being of small size in the south-eastern corner of our study area, we used observations 
from our database, completed with views from Google-Earth.

\subsection{Venues}

The volcanic venues in this area are of different types (Figure 16). Several outcrops correspond to intrusions that are elongate in map view (Figure 16(A)-(A'), Figure 16(B)-(B'), Figure 16(C)-( $\left.C^{\prime}\right)$ ). In less eroded areas, elongate volcanoes (Figure 16(E)-(E')), including domes (Figure 16(D)-( $\left.D^{\prime}\right)$ ), $f$ in Figure 16(E)-(E')) can be observed. The major axes of the elongate volcanoes are interpreted to have the strike of the original open tectonic feature. In (Figure 16(A), Figure 16(F)-(F')) we found good examples of a cluster of aligned volcanoes, in (Figure 16(G)-(G')) and there is a cluster of aligned volcanoes adjacent to each other. In D', the d-d" line on the Google-Earth image exposes a cluster of aligned adjacent small volcanoes, along a fracture zone. In each of these cases the open tectonic feature is supposed to correspond to the line. However, many other volcanic venues do not have a preferred orientation.

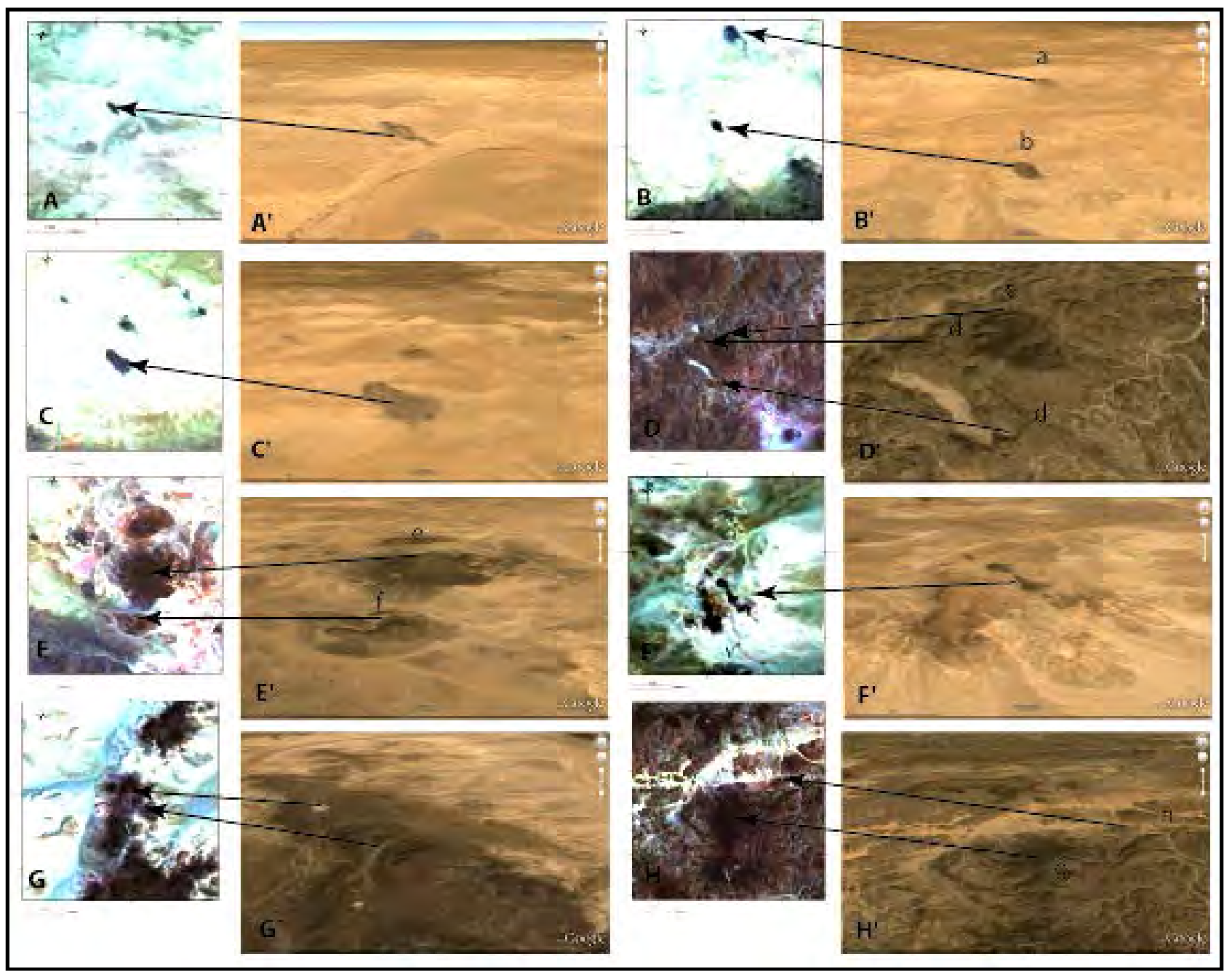

Figure 16. The volcanic venues are shown in extracts of Landsat images (square images) together with the Google-Earth oblique view, looking north. Arrows show the correspondences. 
The volcanic venues in the study area have a peculiar distribution, most of them forming a large group in the SW, and three smaller groups in the north and east (Figure 17). The major axes of elongate venues or lines of clusters of volcanoes, in Figure 17 can be sorted according to their strikes (E, east; N, north; NW, northwest), displayed in different colours. The most frequent strike is NW to WNW, occurring in all groups, but forming almost all the venues in the SW group. Because in general magmas use open large tension fractures as ways up to the surface [12]-[18], we interpret that the more frequent $\sim \mathrm{NW}$-striking family corresponds to vertical tension fractures. Such a field of tension fractures testifies to a stress field characterized by NE extension from NNE to NE, at right angles to the strikes of the tension fractures.

\subsection{Pull-Apart}

Other volcanic venues can be supposed to use open segments along faults, or other tension fractures either of different ages or related to local changes in the stress field [19]. We did not analyse these features.

\section{Sinkholes}

\subsection{Description}

What is generally referred to "sinkholes" in the study area? Are flat-bottomed shallow closed depressions that can be found almost everywhere in the $\mathrm{Al}$

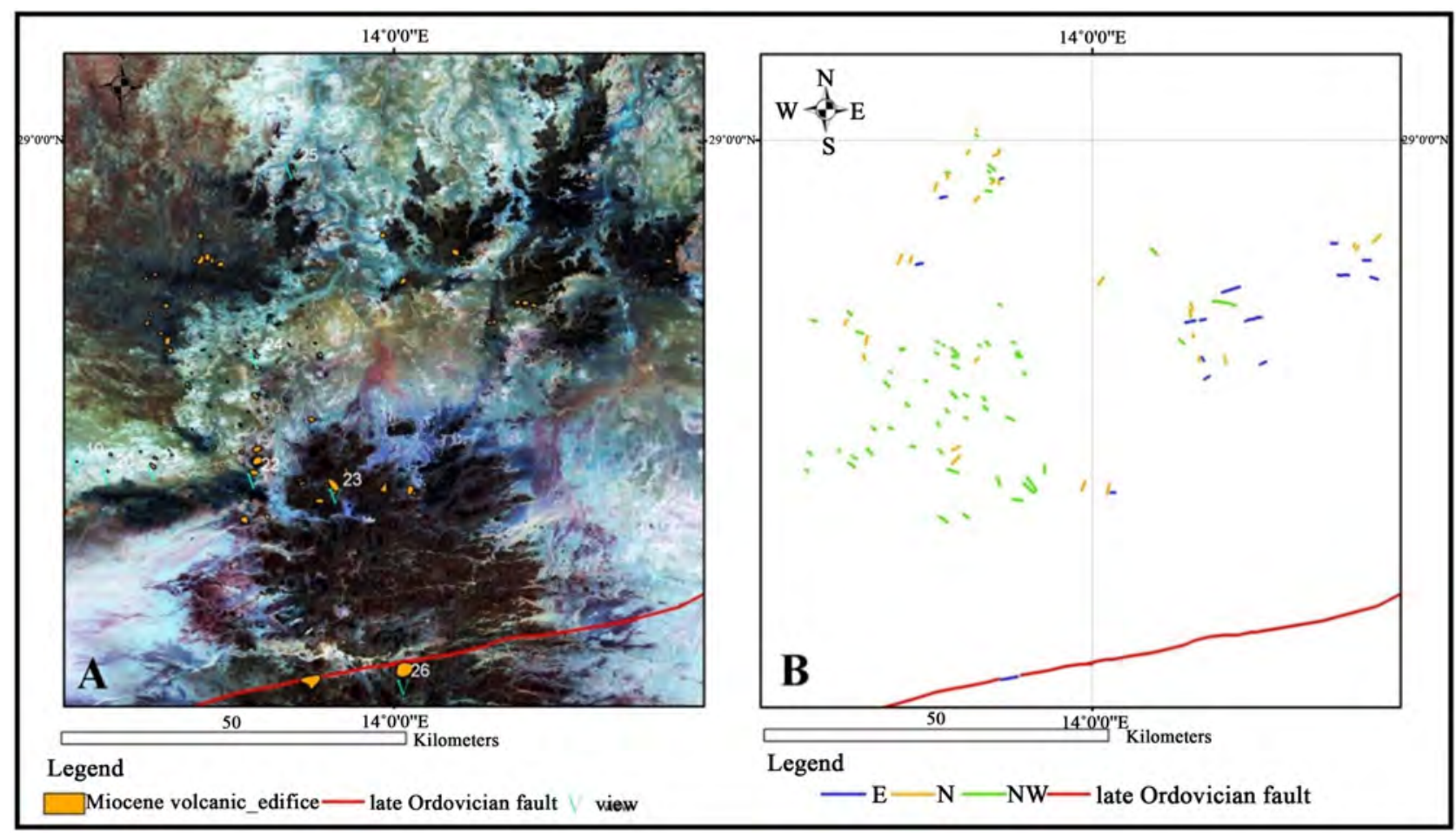

Figure 17. (A) Map of the volcanic venues and major fault of late Ordovician age, its reactivation during the Cenozoic being attested by volcanoes set on its trace; (B) Map of the lines drawn from major axes of elongate volcanic venues or line of clusters of volcanoes. 
Hamra al Hamadah limestone plateau. The concept applies worldwide to closed depressions, from metres to kilometres in dimensions, known for instance in Algeria and others and presently forming in areas such as the Dead Sea. They are supposed to have been formed by dissolution in karstic environment (dolines) in limestones or evaporite rocks or sand, or by erosion in sand-dunes related to sebkahs.

\subsection{Local Sites}

A typical example in the study area is given in (Figure 18). The flat bottom is sharply delineated, bordered by a discrete scarp, oval shaped in map view, with long and short axes respectively $3254 \mathrm{~m}$ and $2132 \mathrm{~m}$. It occurs along a $\sim \mathrm{N} 120^{\circ}$-striking fault scarp, looking NE. The fault morphology is reverse, the uplifted NE compartment being made of Maestrichtian (bluish on the Landsat image) and the downthrown SW one of Paleocene (brownish on the Landsat image). The floor is covered by gravel, and lies only a few metres lower than the structural surface of the NE compartment.

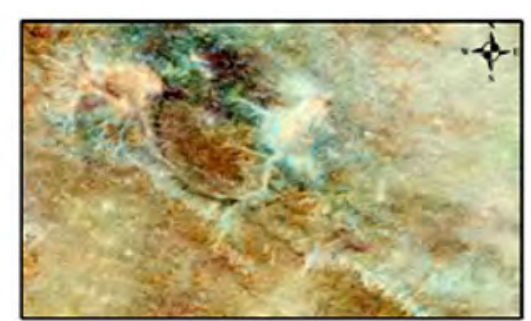

(A)

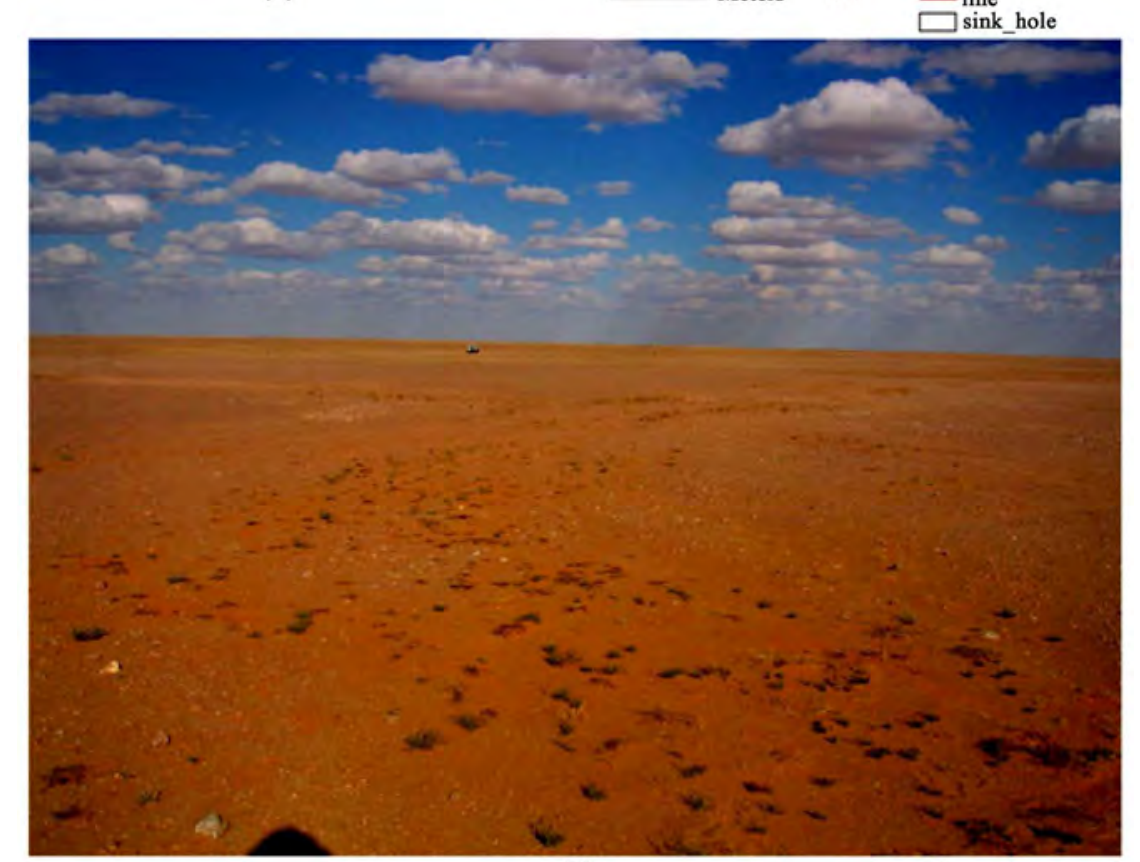

(C)

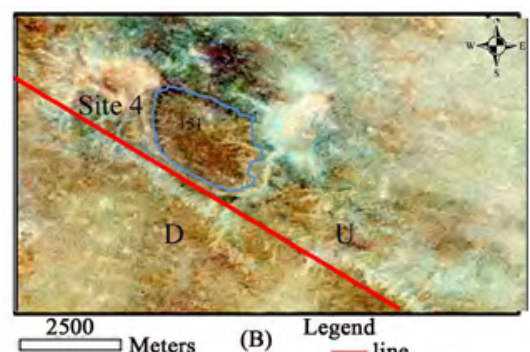

$\square$ sink_hole

Figure 18. Sinkhole 151, oval shaped in map view. Location, E13 ${ }^{\circ} 14^{\prime \prime}$ N29³3". (A) Landsat vertical view; (B) Mapping of sinkhole and fault line; (C) Field view from site 1 to the NE. 


\subsection{Types of Sinkholes}

The sinkholes of the region can be divided into three types based on their shapes (Figure 19): Round shaped; Oval shaped; Sharp ended, at least at one end. Most of them, alike sh151 (Figure 18), are oval-shaped depressions.

The typical shapes of the example of (Figure 19) are sometimes altered by fluvial erosion, resulting in larger sinkholes such as sinkhole 2 of (Figure 20).

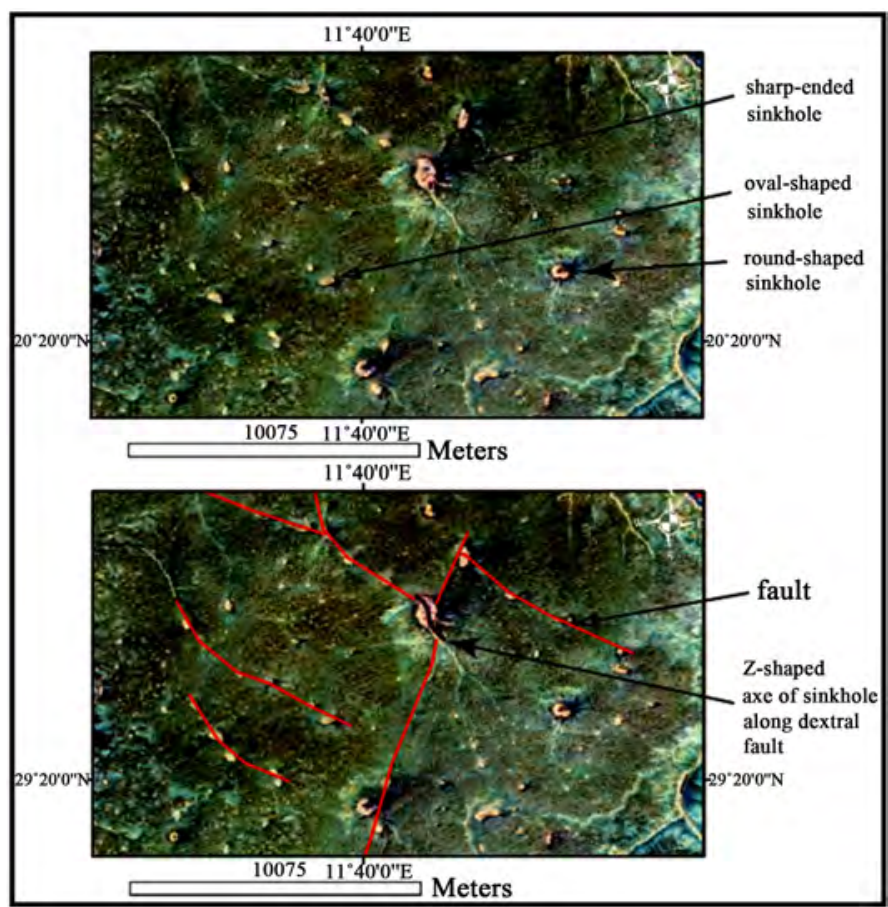

Figure 19. Types of sinkholes, in vertical views on Landsat images.
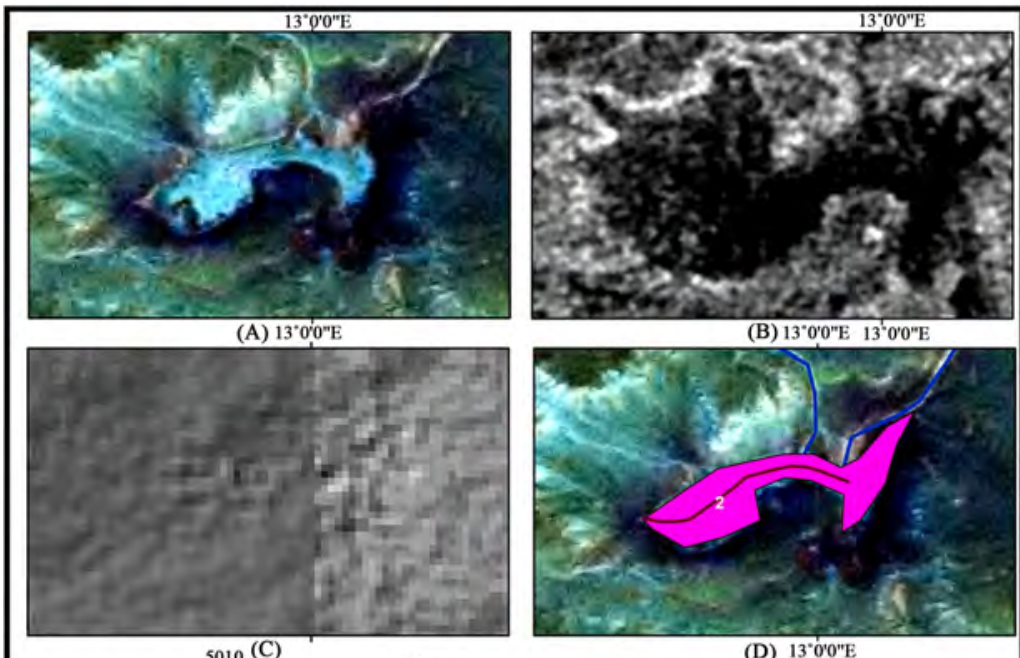

5010 (C)

Meters

(D) $13^{\circ} 0^{\circ} \mathrm{O} \mathrm{E}$

Figure 20. Large sink-hole where fluvial erosion has played a large part, shown by irregular shape and large dimension (length-4 km). (A) Landsat image; (B) Radar image; (C) SRTM DEM image; (D) Map and main axis. The original depression is supposed to have been a Z-shaped narrow tectonic opening, subsequently widen by erosion. 


\subsection{Sinkholes (Tension Fractures)}

The sinkholes generally, the same way the dolines of karstic regions, are considered to have been generated under very humid climate, mainly by in-depth dissolution and subsequent collapse of limestones or evaporite. It is true that in our study area the sinkholes lie in limestones of late Cretaceous to Paleocene age. However, given the present-day arid climate it should be difficult to find a heavily rainy time interval in the past, necessary to generate dolines by karstic dissolution. The area lacks of other typical karstic features such as lapses on top of layers" surface, caves that should be exposed along the cuestas formed by boundaries of the Cretaceous and Paleocene rocks of the plateau, or simply underground gallery networks. For these reasons it must be envisaged another origin for the sinkholes in this region. Many of the sinkholes in the area of study have a simple oval shape in map view, with the major axe of the ellipse trending NW to WNW and their dimensions are a few kilometres, as is the case for sinkhole 1 (Figure 21). It is interesting to notice that most of the volcanic venues lying in the south-eastern corner of the study area have the same characteristics in shape and dimensions, and they are interpreted in previous at "Volcanism and tectonics" to be related mostly to the opening of tension fractures having given a way up to the magma that has filled the gaps. For reason of similarity, we interpret the sinkholes, or at least most of them, to have a tectonic origin. They may have been generated first as open tension fractures, and subsequently filled by detritic material originated from the surface instead of magmatic material from the depth as is the case in the volcanic area.

Tension fractures, which originally should be straight (Figure 21) may also be tectonically modified to form Z- or S-shaped openings, as is suggested for example respectively by (Figure 20) and (Figure 22).

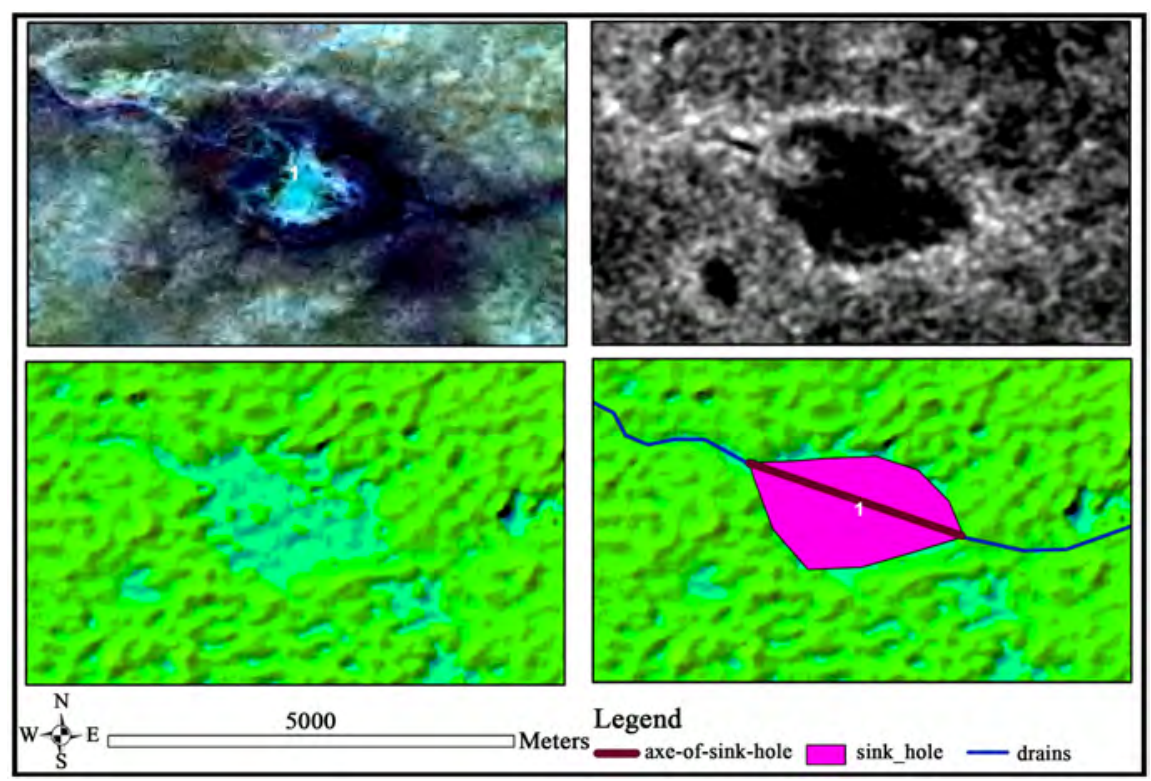

Figure 21. Example of oval-shaped depression, with major axe trending N110 ${ }^{\circ}$, supposed to be that of a simple open tension fracture. 


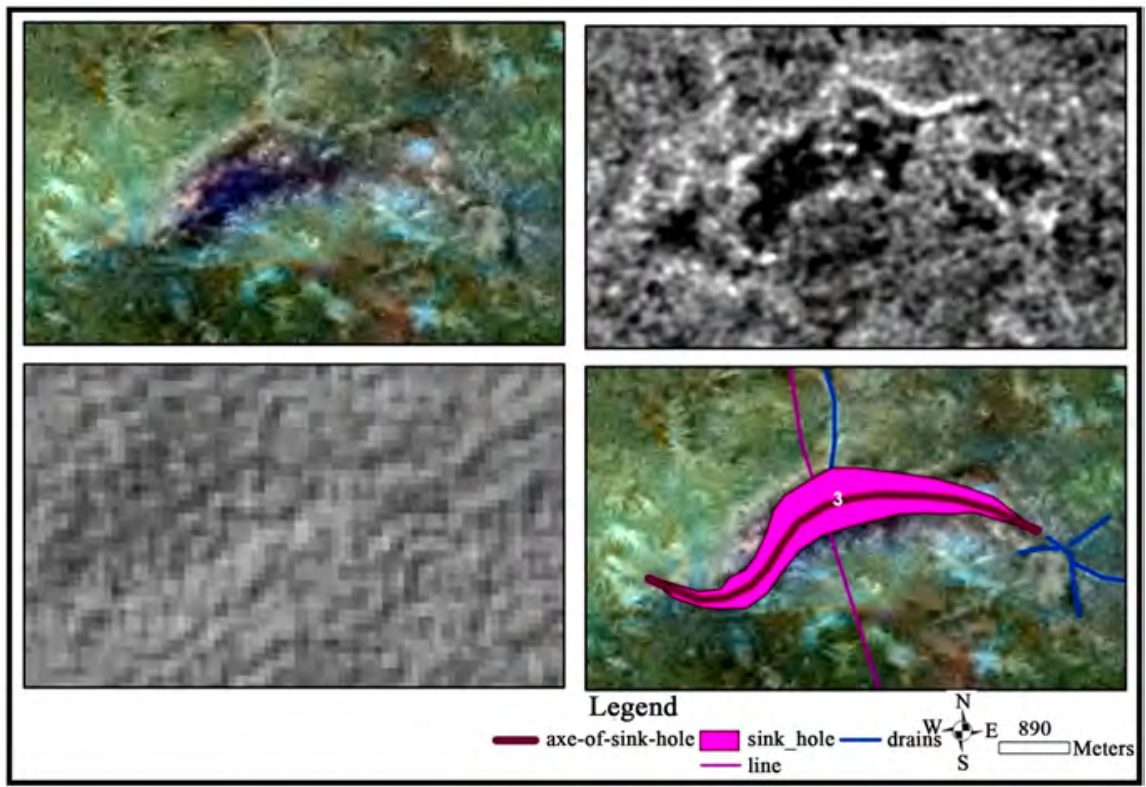

Figure 22. S-shaped sinkhole sharp-ended depression.

The en-echelon geometry of tension fractures along faults may show-up the horizontal component of the movement. For example, in (Figure 23), the arrangement of the sinkholes, supposing they are tension fractures, is consistent with respectively sinistral (A and $\mathrm{B})$ and dextral ( $\mathrm{C}$ and $\mathrm{D})$ horizontal movement components. The Z-shape of the axes of sinkholes in $\mathrm{C}$ and $\mathrm{D}$ is also consistent with dextral throw component.

The en-echelon distribution of some groups of tension fractures, with sometimes no evident fault line observed to link them, confirms that the fault throws are small. The tail-crack configuration of (Figure $14(\mathrm{G})$ and Figure $14(\mathrm{H})$ ) is typical of a NE-striking fault, with small dextral throw component ending in an opening equivalent to a tension fracture. Aside the tension fractures, other tectonic sinkholes may also occur along faults having a strike-slip component, the irregularities along the fault trace being responsible for the opening of pull-apart features. A demonstrative example is that of (Figure 24). Dextral dog-leg irregularities along the fault are responsible for the opening of right stepping pull-apart features.

Some sharp-ended sinkholes of the type of (Figure 25) can be explained to originally correspond to pull-apart openings along faults, even if the fault expression on the surface is faint.

\subsection{Age Determination}

The sinkholes affect the late Cretaceous to Paleocene limestones. Their axes trend the same as that of the volcanic venues, which argues that their formation are of the same age, possibly Miocene (?) to Quaternary. They subsequently have been submitted during a more or less long time to the weathering-erosion agents, but their initial shapes are not lost. 


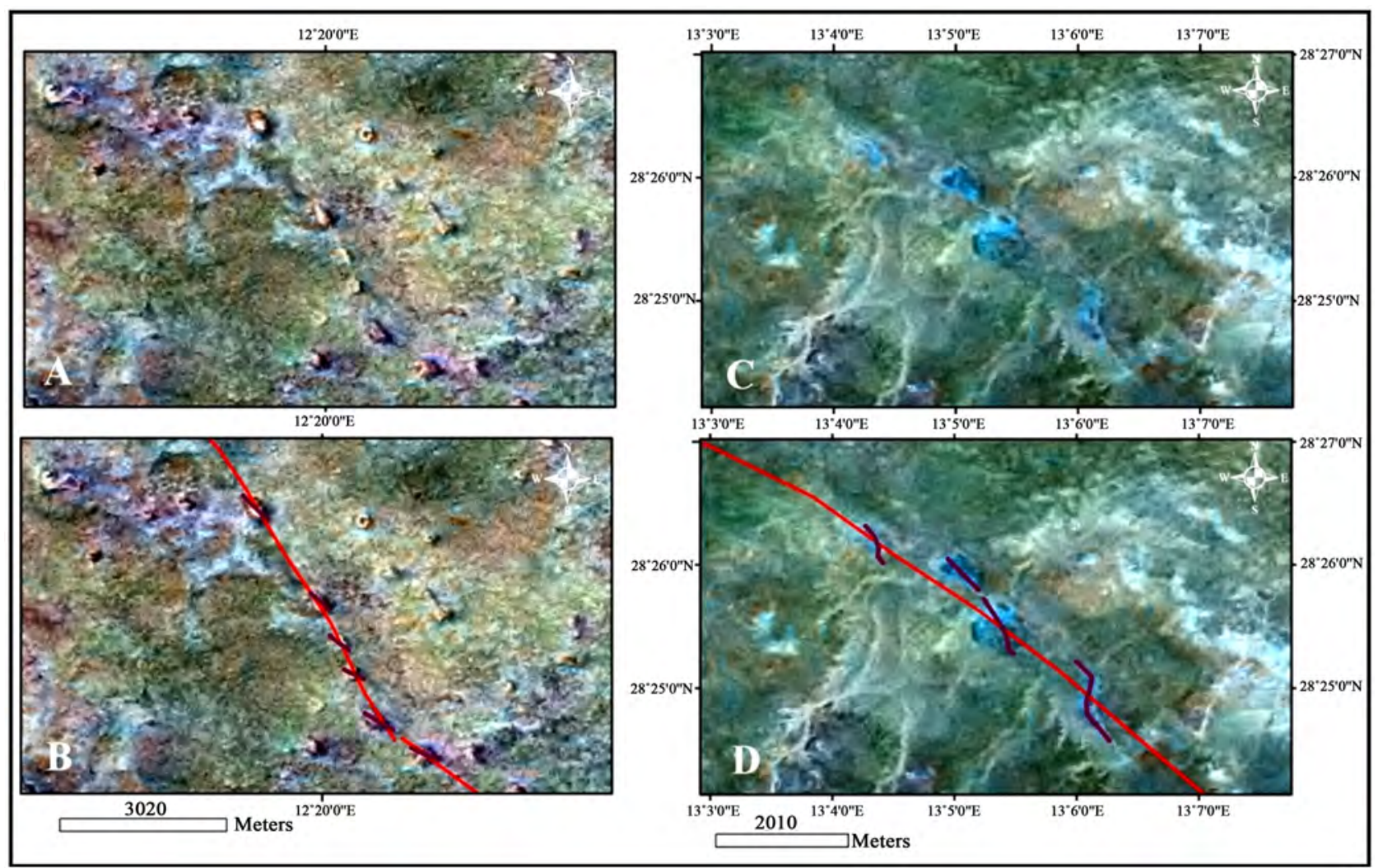

Figure 23. En echelon sinkholes, interpreted to be tension fractures, showing sense of movement along faults on which they are aligned. (A) (B) Sinistral component; (C) (D) Dextral component, consistent with the Z-shape of the axes of sinkholes.

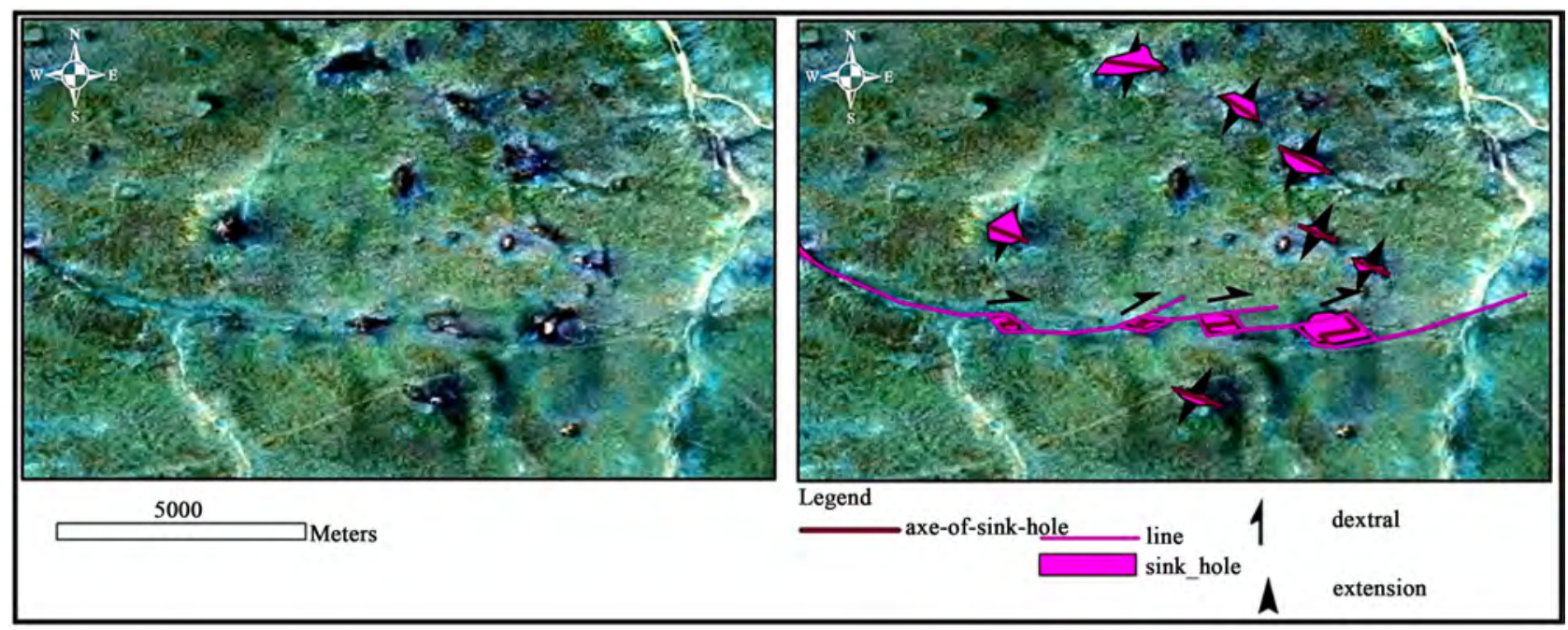

Figure 24. Example of rhomb-shaped depressions along a distinct fault line, showing right-lateral movement, and elliptic-shaped depressions showing the related NNE-trending nearby extension direction. Other oval-shaped sinkholes are supposed to be tension fractures whose axes indicate a NNE-SSW extension.

\section{Interpretations and Discussions}

\subsection{Regional Extension during the Cenozoic}

\section{1) Tectonic event}



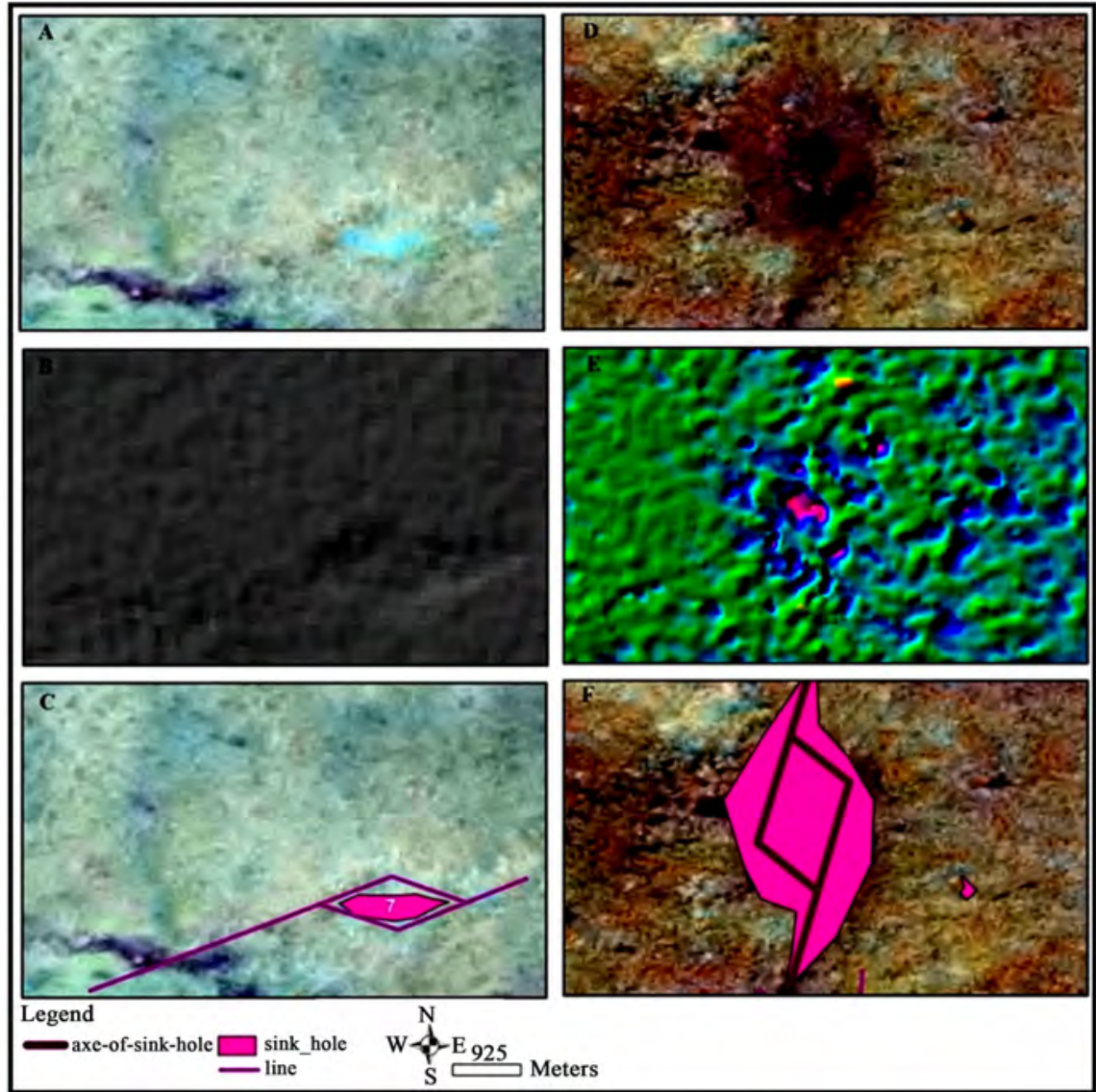

Figure 25. Examples of rhomb-shaped depressions, along a right-lateral motion (images (A), (B), (C)), and along a left-lateral motion (images (D), (E), (F)). Images (A), (B), (C) are of depression no. 7. Images (D), (E), (F) are of depression no.8. (A) and (D): Landsat images. B: shadowed SRTM DEM. E: shadowed and hypsometric colours of GDEM. (C) and (F): mapping.

The tectonic open features that are responsible for the volcanic venues and sinkholes initiations are post-Paleocene in age, for sure. The corresponding tectonic event(s) is partly coeval with the long duration evolution of the Hon graben (post-Eocene). Graben formation is normally long duration, in which the initiation of tension fractures occurs normally early in time, at inset of regional tension [20]. After initiation of a graben, it has its own, long evolution. The occurrence of volcanism is somewhat different. In a tensional environment, formation of magma in depth, possibly related to thinning and weakening of the crust should be the main event inducing a phase of tension fractures and coeval volcanism. We interpret that, in the Hamadah al Hamra plateau, the faulting, and sinkhole tension fractures are related to the initial onset of the regional tensional tectonics, which is also responsible for the initiation of the Hon graben in the late Eocene-Oligocene time? In the volcanic area, the tectonic event may have occurred later (Miocene as mentioned in geological maps) related to formation of magma in depth. There was possibly a long duration stable regional tensional stress-field, which was the frame successively of: 1) formation of the sinkhole 
tension fractures during the late Eocene, 2) opening of the Hon graben from Oligocene time on, and fault movements generating pull-apart sinkholes, 3) opening of the volcanic venues tension fractures during the (Miocene?)-Pliocene-Pleistocene.

\section{2) Tension fractures}

Most of the openings in the study area are vertical tension fractures (Figure 18; Figure 21), spread all over the study area (Figure 26). Their distribution seems mainly random, except for the tension fractures aligned in en-echelon patterns. At each vertical tension fracture, the local extension is horizontal, at right angle to the strike of the tension fracture. Altogether these extension trends evidence a homogeneous stress field trending mainly NNE-SSW, which should be also that initiating later the formation of the Hon graben. Compared to the main NW-SE orientation of the Hon graben, it appears that this trough started its evolution by an oblique opening, which is a frequent case for graben [21].

\section{3) Faults}

The major fault family of post-Paleocene age strikes WNW. Other faults strike ESE to $\sim$ E (Figure 27). Some other faults strike SSE, paralleling the Hon graben, and there are many faults striking $\sim \mathrm{N}$, but their trace is generally not straight. The interpretation of the sinkholes in terms of tension fractures or pull-apart

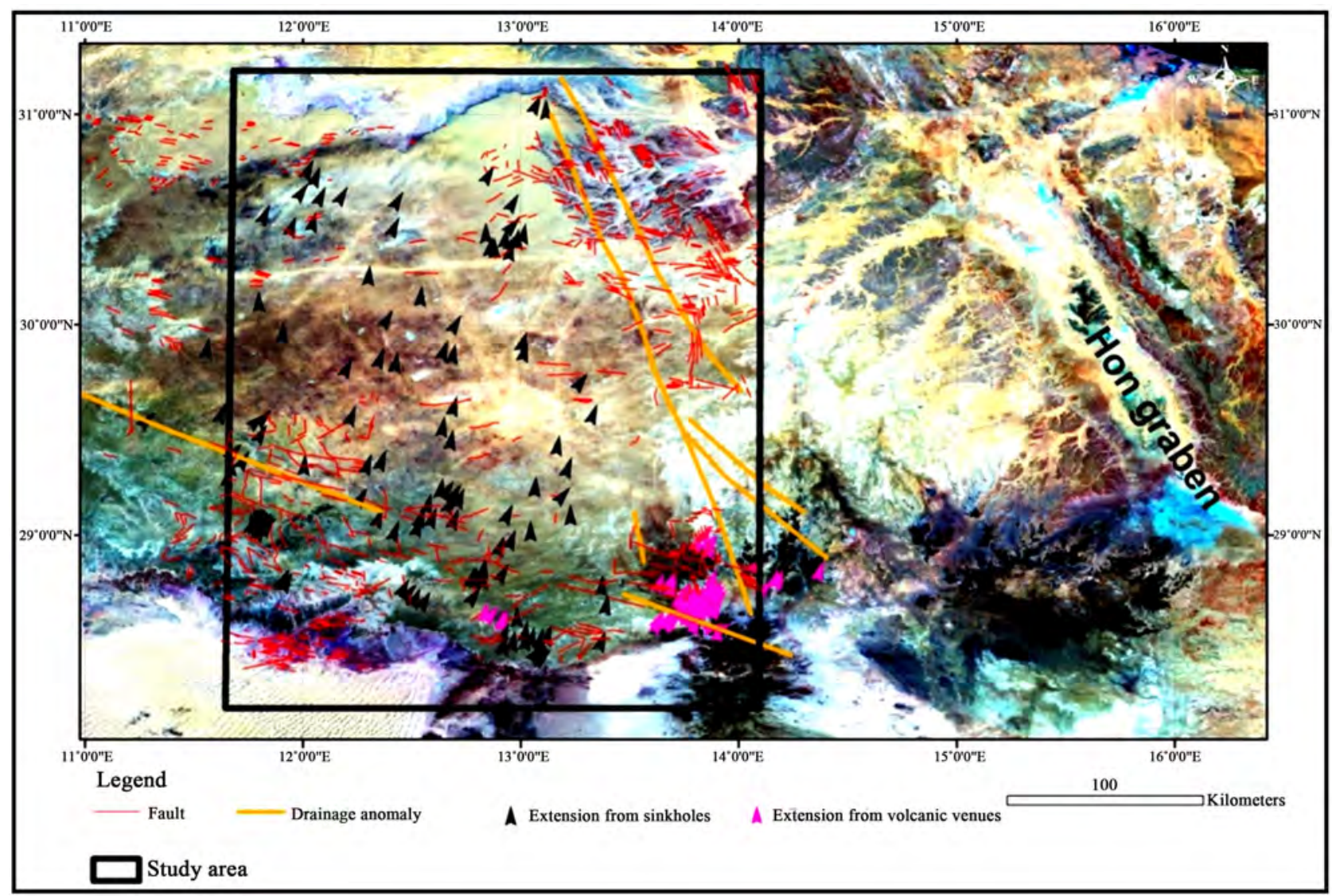

Figure 26. Distribution and orientation of extension direction drawn at right angle to the tension fractures deduced from sinkholes or volcanic venues. Observations in the study area can be compared to the orientation of the Hon graben. 


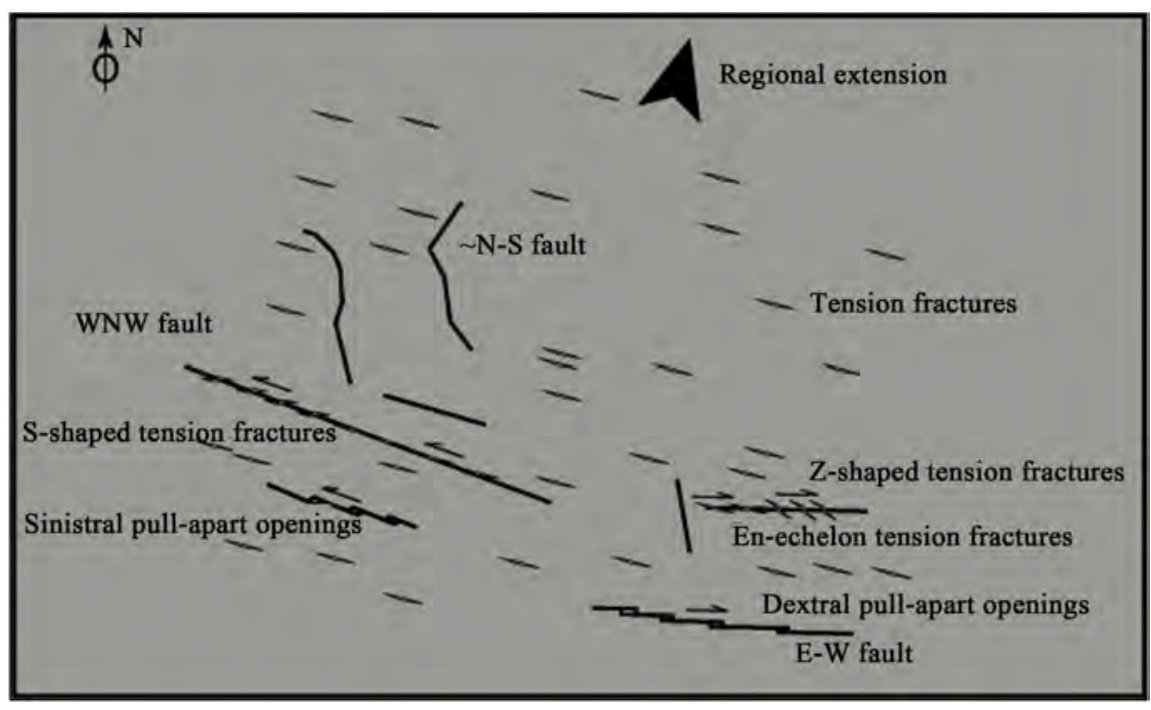

Figure 27. Tectonic scheme of the study area. Main faults strike WNW or E-W. Some are more or less N-S. The regional extension is NNE, parallel to the bisecting line of obtuse angle between WNW and E-W faults. The WNW and E-W faults may show evidences of strike-slip movement component, respectively sinistral and dextral, by geometry of pull-apart features, en-echelon tension fractures and S- or Z-shaped tension fractures.

openings is consistent with respectively left-lateral and right-lateral mechanism of fault families. The regional extension is at right angle to the axes of most of the tension fractures (Figure 26). The tension fractures areen-echelon and deformed into $\mathrm{S}$ or Z-shapes, respectively along the sinistral WNW- and $\mathrm{N}$-striking or along the dextral E-striking faults. The shapes of pull-apart openings along faults, related to strike-slip movement components, which are consistent with this interpretation; they correspond to left-stepping dog-legs along WNW-SSE or $\sim \mathrm{N}-\mathrm{S}$ faults, and right-stepping dog-legs along E-W faults (Figure 14 and Figures 23-25).

All of these features testify to right-lateral movement component along the E-W faults (Figure 25(c)), conjugate left-lateral movement component along the WNW-ESE faults (Figure 25(f)).

\section{4) Relationships with Palaeozoic structures}

\section{Wadi Hawaz}

Straight anomalies in a drainage network are often interpreted to be related to fractures (joints and faults) that, when they appear in a sedimentary rock series and are long distances, may be due to reactivation of deeper major discontinuities. This hypothesis can be tested following the main talwegs and tributaries of Wadi Hawaz (Figure 28), which steps down the cuesta from the plateau and ends into dunes covering the basement. Observations along the talweg that successively cross the late Cretaceous-Paleocene layers and the Cambrian Ordovician rocks show the relationships between structures from top to bottom of the series.

The plateau series, comprising a horizontal succession of Paleocene, Maestrichtian and Campanian limestones, uncomformably rests on almost horizontal 


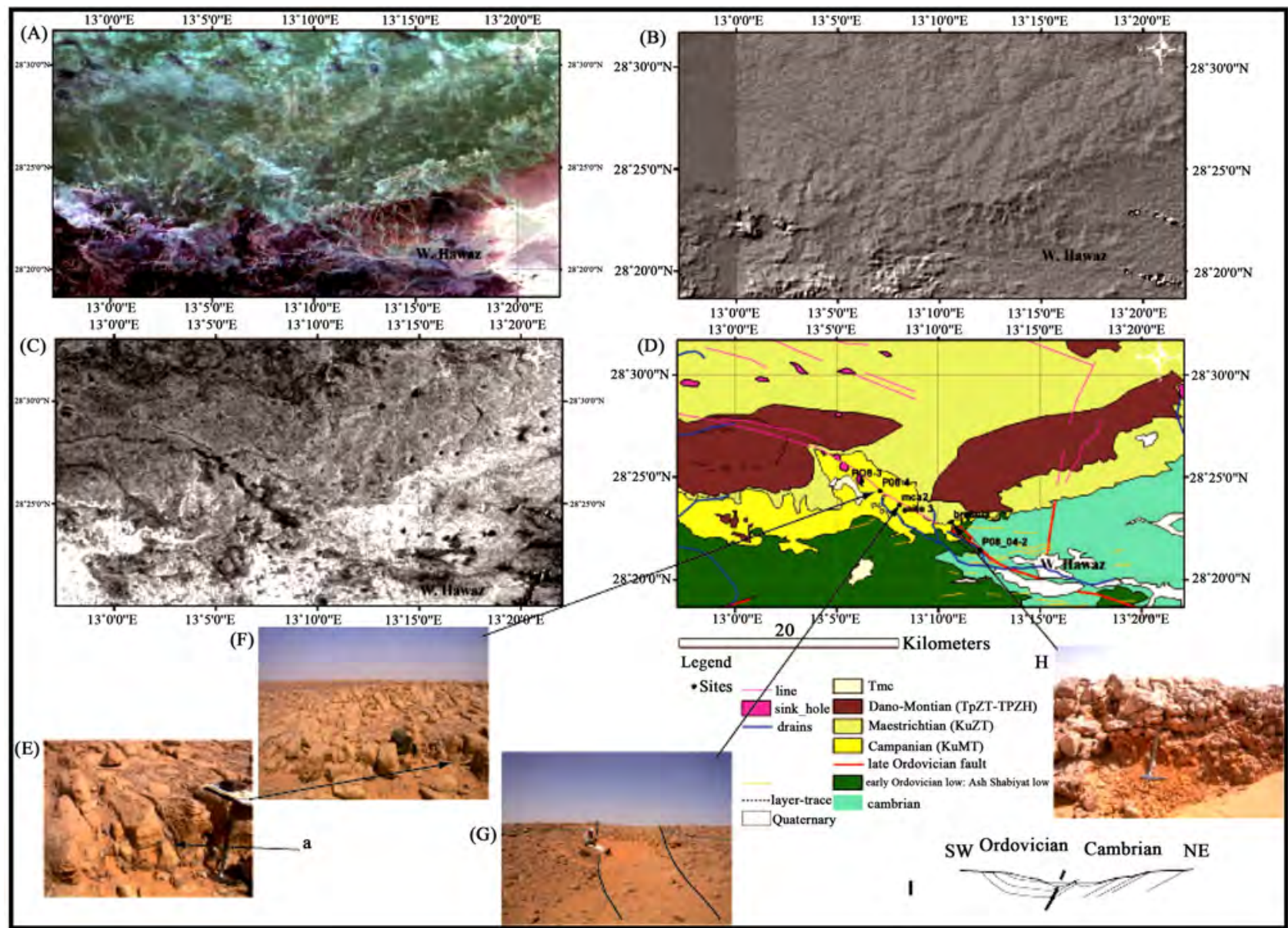

Figure 28. Mapping and field observations along a fault zone affecting late Cretaceous-Paleocene layers and Palaeozoic rocks.

early Ordovician (lower part) Ash Shabiyat rocks, lying over Cambrian sandstones (Figures 28(A)-(C)). Syn-sedimentary dikes cross the Palaeozoic rocks, as well as faults, a $\mathrm{N} 130^{\circ}$-striking one (WadiHawaz fault) and a $\mathrm{N} 10^{\circ}$-striking one (Figure 28(D)). Both are dis-conformably covered by the Campanian rocks but lines can be drawn in their along strike continuation on the surface of the plateau border (Figure 28(C)). WadiHawaz follows the $\mathrm{N} 130^{\circ}$ fault downstream, and upstream it is parallel to these lines in the same direction. In site P08-3 a "sinkhole" depression, $650 \mathrm{~m}$ wide, ends to the NW in a linear depression $80 \mathrm{~m}$ wide, in which there is no individualized talweg, which would be regarded as a fracture line. In site P08-4, a layer of yellow marly limestone belonging to the Maestrichtian (Mizda formation) forms a scarp, on which clearly appears a $20 \mathrm{~m}$ wide zone of $\mathrm{N} 150^{\circ}$-striking vertical joints, each $2 \mathrm{~cm}$ open, spaced every $25 \mathrm{~cm}$, filled by the same dark pink limestone than the overlying layers (Figure 28(E) and Figure 28(F)). This fracturing was active during deposition of the late Cretaceous limestone. (Figure 28(G)), a sedimentary dike (Figure $28(\mathrm{H})$ ), and monogenetic breccia whose elements are the same rock as the layers above and below, evidence sedimentary instability during the Campanian, probably related to the activity of syn-depositional faults. 
The cross-section of the Palaeozoic fault (Figure 28(I)) expresses an important normal movement during that time. On the whole, it seems that faint fragile deformations of the late Cretaceous-Paleocene layers, occurred during their deposition and later on, up along the trace of the Palaeozoic fault. The Cretaceous and Cenozoic deformation can be considered to be influenced by the presence of the Palaeozoic faults, which should have been slightly reactivated.

\subsection{Reactivation of Palaeozoic Faults}

Comparing (Figure 15) and (Figure 29), [21] it is clear that the main post-Paleocene fault direction families in the Al Hamadah al Hamra plateau on the one hand, and the Palaeozoic main fault families in the Al Qarqaf Arch are the same. The families are also the same in the Miocene (?) basalt, implying that part of the reactivation occurred during the Miocene (?). The WNW- to ESE-striking Palaeozoic faults have a noticeable strike-slip component, and these

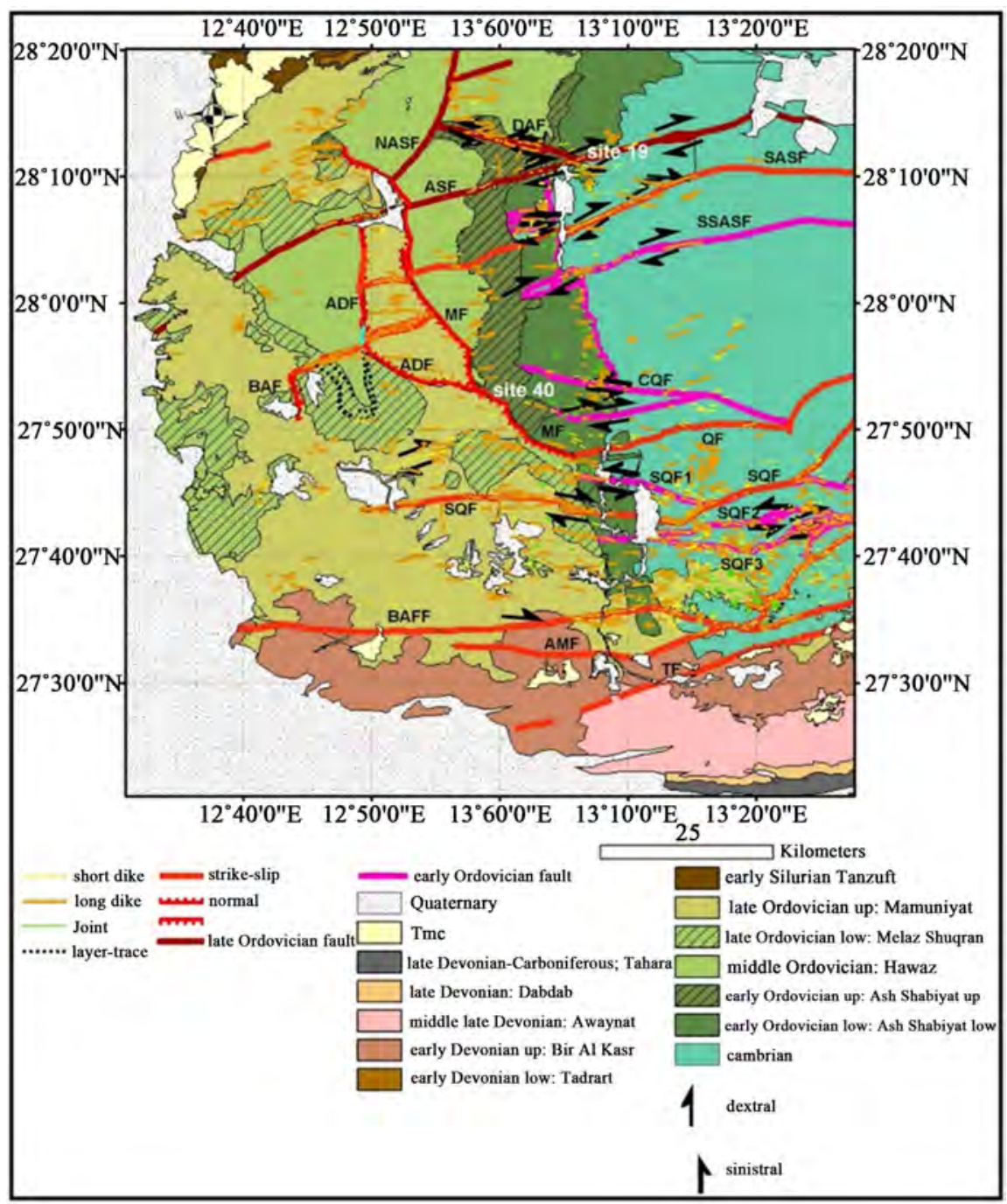

Figure 29. Fracturing in Western Al Qarqaf study area is obtained from remote sensing analysis. Black arrows: fault movements during the Palaeozoic [5]. 
horizontal throws are major along the Al Qarqaf arch, which has acted as a transfer fault zone during that time [21]. The $\sim \mathrm{N}-\mathrm{S}$ striking faults are mainly normal, with large vertical throws of several hundred meters. On the contrary, all the Cenozoic faults in the plateau have a faint throw, only a few tens of metres, and they are mainly normal or oblique-slip. The correlation of the fault strikes, but not of the quantities of movements, argues faint reactivation of the Palaeozoic faults by the Cenozoic extension, during the Cenozoic tectonic environments. Another clue for reactivation is that the Cenozoic fault density is higher when approaching the Qarqaf arch, and decreases northwards, probably correlated with higher density of Palaeozoic faults along the transfer fault zone, and lower density in the nearby Ghadamis basin.

The style of reactivation however is unclear. According to our observations along wadi Hawaz, few movements had occurred during deposition of the late Cretaceous-Paleocene sediments, over unstable Palaeozoic faults. And these weak lines may have afterwards reacted under effects of the Cenozoic extension. Another possibility, which does not exclude the previous one, is that small movements along the Palaeozoic faults in depth initiating ruptures in the unconformable sedimentary pile. This mechanism may also explain the formation of tension fractures, at random or at the vertical over the deep faults.

1) Folds

The axes directions of anticlines affecting the Cretaceous-Paleocene rocks are also parallel to the main strikes of the Palaeozoic faults. They should be then related in some way to the old structures. However, there is no Cenozoic compression observed in the study area that would be responsible for folding during this time. The folds do not form en-echelon successions, or belts which would indicate a compressional or strike-slip Cenozoic stress field. In a first hypothesis, we suggest that faint tensional Cenozoic deformation, mainly expressed by faults, have induced small vertical relative displacements of blocks, and those which are in horst situation may induce formation of anticlines in the Mesozoic-Cenozoic layers. However, some of the faults bordering these "horst anticlines" should have finally express along the sides of the folds, at least partly. But we did not find such faults along the fold borders. In a second hypothesis, we suggest that the concentration of a large part of the oil and gas in deep trap structures of Palaeozoic age has occurred after the deposition of the late Cretaceous-Paleocene series. As a consequence, this income of oil material, of density lower than the reservoir rocks, may have produced faint uplift of the plateau surface, forming gentle anticlines. This phenomenon can be conceived to be similar to the faint subsidence affecting an oil and gas field during time of extraction.

\section{2) Argument}

An argument favours the second hypothesis. Anticline A2 has been evidenced by deep valleys (Figure 11) showing recent (Quaternary?) uplift of this fold. This argument is consistent with a possible recent ascension and concentration of oil materials in depth. Strike of folds is similar to mains strikes of faults in the basement: traps linked with faults (push-up structures? fault traps, stratigraphic 
traps linked with syn-sedimentary faulting, normal faults and their related drag folds.

\section{Conclusions}

Remote sensing analysis is an efficient tool for updating geological maps. The regional scale map obtained in this project from compilation of the pre-existing maps and of a number of space images is somewhat more complete. It takes into account the usual field and laboratory parameters of the rock units, through the previous geologic maps, together with remote sensing parameters such as spectral signatures, textures, roughness, morphology that are observed from optical, microwave and DEM imagery. With more rock characteristics, the old maps are obligatorily improved.

The new mapping and the shadowing of DEMs have evidenced a series of gentle anticlines with axes trending NNE-SSW to NNW-SSE, affecting the late Cretaceous-Paleocene plateau, which were previously all but one unknown. As for their genesis, they don't seem to correspond to a compressional tectonic phase. We favour a hypothesis based on their rather Cenozoic age, which implies that concentration of low density oil material in depth, inside the Palaeozoic traps, and subsequent tendency to uplift, should have been transferred across the late Cretaceous-Paleocene sedimentary pile, and up to the surface. The uplift of anticlines was of the order of $20 \mathrm{~m}$ maximum.

The analysis of hydrologic network anomalies has resulted in the mapping of a few lineaments and of part of the faults. In the southern part of the Ghadames basin, a WNW-trending lineament, forming the northern boundary of a great number of faults striking the same, seems to mark the northern boundary of the densely fractured Al Qarqaf arch, which was a strike-slip transfer fault zone during the Palaeozoic time interval. To the east of Ghadames basin, $\mathrm{NNW}$-trending lineaments seem to represent the western boundary of the area subjected to faulting related to evolution of the Hon graben.

Another major outcome of this study is that interpretation of the numerous sinkholes spread all over the area, in terms of tectonic openings such as tension fractures or pull-apart features, is consistent with the tectonic framework. A stable, long duration (late Eocene to Quaternary) regional tensional stress-field was oriented NNE-SSW. It is responsible for genesis of the tectonic sinkholes, faults, the Hon graben and volcanism. The volcanic venues in south-eastern part of the study area are related with the opening of tension fractures during the (Miocene?)-Pliocene-Quaternary time.

The Cenozoic faulting in the Al Hamra al Hamadah plateau is largely influenced by the tectonics affecting the Palaeozoic oil bearing structures that are hidden by the late Cretaceous-Paleocene layers. The tectonic style is that of reactivation of the Palaeozoic faults under effects of the NNE-trending regional tension. Then the faults on the surface of the plateau would indicate location of the hidden Palaeozoic faults in depth. 
A flat plateau, in the arid environment, appears to be a very favourable environment for mapping of gentle folds, faults and tectonic sinkholes. Remote sensing is a fruitful approach in this case study. The gentle anticlines for instance are undetectable in the field, but computer assisted shadowing with a low elevation angle of illumination is the key processing for evidencing these features.

Our study went into details identifying the locations of the sinkholes in Ghadames basin and especially in the areas as showed in the previous figures. Problems of drillings in the area are well known for example to Waha, AGOCO and PB Companies during their exploration activities in the concessions in Ghadames Basin. According to them several incidents of losing drilling Pits have occurred and drilling came into a hole. Because this paper is aimed to know the exact location of sinkholes in the Ghadames basin, I would recommend all the oil companies to review this work and try to trace the sinkholes indicated to minimize the risk of drilling problems.

\section{Conflicts of Interest}

The authors declare no conflicts of interest regarding the publication of this paper.

\section{References}

[1] Conant, L.C. and Goudarzi, G.H. (1967) Stratigraphic and Tectonic Framework of Libya. American Association of Petroleum Geologist Bulletin, 51, 719-730.

[2] Gumati, Y.D., Kanes, W.H. and Schanel, S. (1996) An Evaluation of the Hydrocarbon Potential of the Sedimentary Basins of Libya. Journal of Petroleum Geology, 19, 95-112. https://doi.org/10.1111/j.1747-5457.1996.tb00515.x

[3] Bellini, E. and Massa, D. (1980) A Stratigraphic Contribution to the Paleozoic of Southern Basins of Libya. In: Salem, M.J. and Busrewil, M.T., Eds., Geology of Libya, Academic Press, London, 3-56.

[4] Goudarzi, G.H. (1980) Structure-Libya. In: Salem, M.J. and Busrewil, M.T., Eds., Second Symposium on the Geology of Libya, Vol. 3, Academic Press, London, 879-892.

[5] Echikh, K. (1992) Geology and Hydrocarbon Potential of the Ghadamis Basin. Internal Report, National Oil Corporation of Libya (NOC), Tripoli.

[6] Industrial Research Centre (IRC), Tripoli-Libya (1983-1985) 1:50,000, 1:250,000 and 1:1000,000 Geological Map Sheet Series from the Libya. Geological Map of Libya 1:250.000: Qarārat Al Marār NH 33-13, Sheet: Habayt Al Ghardqah.

[7] Deffontaines, B. and Chorowicz, J. (1991) Principle of Hydrographic Network Analysis from Multisource Data. Application to Structural Analysis of the Zairian basin. Tectonophysics, 194, 237-263. https://doi.org/10.1016/0040-1951(91)90263-R

[8] Chorowicz, J. and Deffontaines, B. (1993) Transform Faults and Pull-Apart Model in the Rhinegraben from Analysis of Multisource Data. Journal of Geophysical Research, 98, 14339-14351. https://doi.org/10.1029/93JB00190

[9] Howard, A.D. (1967) Drainage Analysis in Geologic Interpretation: A Summation. American Association of Petroleum Geologist Bulletin, 51, 2246-2259.

[10] Chorowicz, J. (1980) Mise à jour de notions utilisées par les géologues en télédétection. Hommes et Terres du Nord, Télédétection, 5, 203-206. 
[11] Peregi, Z., Less, G., Konrad, G., Fodor, L., Gulacsi, Z., Gyalog, L., Turki, S.M., Suwesi, S.K., Sherif, K. and Dalub, H. (2003) Geological Map of Libya 1:250,000, Sheet Al Haruj al Abyad, NG 33-8. Explanatory Booklet, 250 p. Industrial Research Centre, Tripoli.

[12] Chorowicz, J., Bardintzeff, J.M., Rasamimanana, G., Chotin, P., Thouin, C. and Rudant, J.P. (1997) An Approach to Relate Tension Fractures to Volcanic Vents: Examples from Iceland and Madagascar. Tectonophysics, 271, 263-283. https://doi.org/10.1016/S0040-1951(96)00250-8

[13] Korme, T., Chorowicz, J., Collet, B. and Bonavia, F.F. (1997) Volcanic Vents Rooted on Extension Fractures and Their Geodynamic Implications in the Ethiopian Rift. Journal of Volcanology and Geothermal Research, 79, 205-222. https://doi.org/10.1016/S0377-0273(97)00034-6

[14] Adiyaman, Ö., Chorowicz, J. and Köse, O. (1998) Relationships between Volcanic Patterns and Neotectonics in Eastern Anatolia from Analysis of Satellite Images and DEM. Journal of Volcanology and Geothermal Research, 85, 17-32. https://doi.org/10.1016/S0377-0273(98)00047-X

[15] Dhont, D., Chorowicz, J., Yürür, T., Froger, J.-L., Köse, O. and Gündogdu, N. (1998) Emplacement of Volcanic Vents and Geodynamics of Central Anatolia, Turkey. Journal of Volcanology and Geothermal Research, 85, 33-54. https://doi.org/10.1016/S0377-0273(98)00048-1

[16] Adiyaman, Ö. Chorowicz, J., Arnaud, O.N., Gündogdu, M.N. and Gourgaud, A. (2001) Late Cenozoic Tectonics and Volcanism along the North Anatolian Fault: New Structural and Geochemical Data. Tectonophysics, 338, 135-165. https://doi.org/10.1016/S0040-1951(01)00131-7

[17] Adiyaman, Ö. and Chorowicz, J. (2002) Late Cenozoic Tectonics and Volcanism in the Northwestern Corner of the Arabian Plate: A Consequence of the Strike-Slip Dead Sea Fault Zone and Lateral Escape of Anatolia. Journal of Volcanology and Geothermal Research, 117, 327-345. https://doi.org/10.1016/S0377-0273(02)00296-2

[18] Navarro, A., Chorowicz, J., Miranda, J.M. and Catalão, J. (2009) Analysis of Geometry of Volcanoes and Faults in Terceira Island (Azores): Evidence for Reactivation Tectonics at EUR/AFR Plate Boundary in the Azores Triple Junction. Tectonophysics, 465, 98-113.

[19] Chorowicz, J., Emran, A. and Alem, E.M. (2001) Tectonique et venues volcaniques en contexte de collision, exemple du massif néogène du Siroua (Atlas Marocain): Effets combinés d'une transformante et de la suture panafricaine. Canadian Journal of Earth Sciences, 38, 411-425. https://doi.org/10.1139/e00-074

[20] Chorowicz, J. (2005) The East African Rift System. Journal of African Earth Sciences, 43, 379-410. https://doi.org/10.1016/j.jafrearsci.2005.07.019

[21] Chorowicz, J. and Benissa, M. (2016) Remote Sensing and Field Analysis of the Palaeozoic Structural Style in NW Libya: The Qarqaf Arch a Paleo-Transfer Fault Zone between the Ghadamis and Murzuq Basins. Journal of African Earth Sciences, 123, 272-293. https://doi.org/10.1016/j.jafrearsci.2016.08.008 